University of Louisville

ThinkIR: The University of Louisville's Institutional Repository

Electronic Theses and Dissertations

$12-2016$

\title{
"The quality of women's intelligence" : female humanists in Renaissance Italy.
}

Julie Myers-Mushkin

University of Louisville

Follow this and additional works at: https://ir.library.louisville.edu/etd

Part of the Cultural History Commons, History of Gender Commons, and the Women's History Commons

\section{Recommended Citation}

Myers-Mushkin, Julie, "'The quality of women's intelligence" : female humanists in Renaissance Italy." (2016). Electronic Theses and Dissertations. Paper 2618.

https://doi.org/10.18297/etd/2618

This Master's Thesis is brought to you for free and open access by ThinkIR: The University of Louisville's Institutional Repository. It has been accepted for inclusion in Electronic Theses and Dissertations by an authorized administrator of ThinkIR: The University of Louisville's Institutional Repository. This title appears here courtesy of the author, who has retained all other copyrights. For more information, please contact thinkir@louisville.edu. 
“'THE QUALITY OF WOMEN'S INTELLIGENCE': FEMALE HUMANISTS IN RENAISSANCE ITALY"

\author{
By \\ Julie Myers-Mushkin \\ B.A., University of California, Los Angeles, 1998
A Thesis Submitted to the Faculty of the College of Arts and Sciences of the University of Louisville
in Partial Fulfillment of the Requirements for the Degree of

Master of Arts in Women's and Gender Studies

\author{
Department of Women's and Gender Studies \\ University of Louisville \\ Louisville, Kentucky
}

December 2016 



\section{“'THE QUALITY OF WOMEN'S INTELLIGENCE': FEMALE HUMANISTS IN}

RENAISSANCE ITALY"

\section{By}

Julie Myers-Mushkin

B.A., University of California, Los Angeles, 1998

A Thesis Approved on

October 5, 2016

By the following Thesis Committee:

Thesis Director

Dr. Genevieve Carlton

Dr. Nancy Theriot

Dr. Ann Allen 


\section{DEDICATION}

This thesis is dedicated to my greatest teachers,

my children Katie and Zack Mushkin,

who inspire me, love me unconditionally, and always cheer for me the loudest. 


\section{ACKNOWLEDGMENTS}

First and foremost, I would like to thank my instructor and advisor, Dr. Genevieve Carlton, for selflessly giving of her time and sharing her expertise with me over the last year. It has been an honor both to take her Renaissance and early modern seminars and to work with her so closely on my research. Her contributions to my training and this thesis are innumerable.

I would also like to express my heartfelt gratitude to Dr. Nancy Theriot and the Women's and Gender Studies Department at the University of Louisville for the incredible opportunity I was given to pursue my Master's Degree in WGS. I am a better scholar, historian, citizen, and mother because of what I have learned in my program, and being a part of the WGS community has truly changed my life. Also, many thanks to my other committee members, Dr. Nancy Theriot and Dr. Ann Allen, for their time and comments.

Most importantly, I would like to thank my husband, Jeff, my children, Katie and Zack, and my family and friends for their support over the past year. I could not have gone back to graduate school and completed this thesis without the sacrifices they made and encouragement they lovingly gave. 


\title{
ABSTRACT \\ “'THE QUALITY OF WOMEN'S INTELLIGENCE': FEMALE HUMANISTS IN RENAISSANCE ITALY"
}

\author{
Julie Myers-Mushkin
}

October 5, 2016

This thesis examines how the advent of humanism in Renaissance Italy impacted women, namely those who were raised within intellectual families and granted educational opportunities not before afforded to members of their sex. In quattrocento Italy, learned women began to circulate their writings and participate in the humanist milieu, and the intellectual lives and published works of these female humanists all in some manner contested Renaissance patriarchy and gender perceptions. As such, this thesis challenges the conception that the Renaissance further disenfranchised women and offers a framework for analyzing and appreciating the ways in which women participated in the academic dialogue of their time once past the age of sexual maturity. I argue that to fully analyze the myriad of ways in which learned adult women participated in humanism more narrowly, and in the Renaissance more broadly, their engagement with paternal figures, patrons, and patriarchal institutions must be appreciated on an individual basis.

The investigation of Renaissance humanism and the educational opportunities the movement provided for women in Part I contextualizes the social and academic milieu of the four notable learned women presented in the microhistorical, biographical case studies. Furthermore, the case studies support my larger argument that a sexually mature 
female humanist's public reception and career longevity were dependent upon her willingness to adhere to patriarchal ideology and conform to traditional prescriptions of femininity. This thesis, therefore, suggests that historians continue to ask how adult women's experiences were determined by their sexual maturity, marital choices, and relationship with paternal figures, and even more importantly, how adult women continued to meaningfully participate in society in spite of socially mandated limitations on their gender. 
TABLE OF CONTENTS

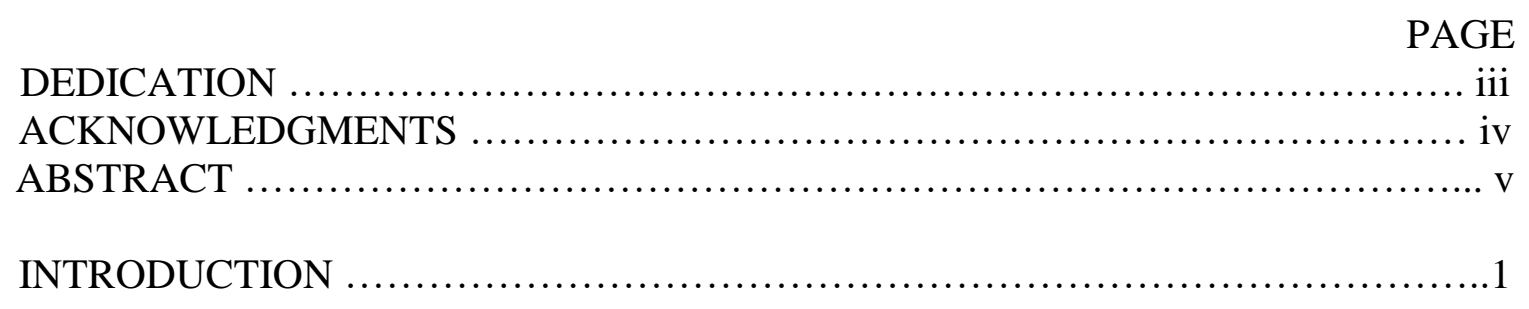

I. THE RENAISSANCE HUMANIST MOVEMENT ............................11

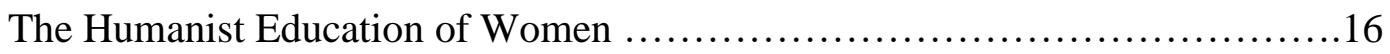

II. BOOK-LINED CELL: THE SOLITARY LIFE OF ISOTTA NOGAROLA ..........21

A Woman in a Man's World .............................................. 24

The Virtue in Monastic Life ........................................28

III. DEFENSE OF THE LIBERAL INSTRUCTION OF WOMEN: THE PUBLIC LIFE

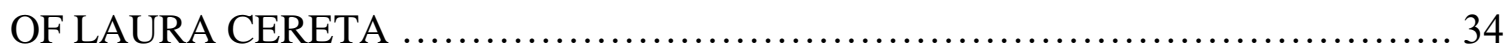



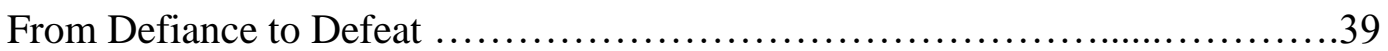

IV. THE WORTH OF WOMEN: THE PRIVILEGED LIFE OF MODERATA

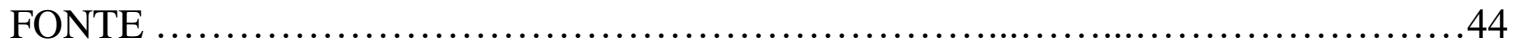

The Making of a Feminist Housewife ....................................45

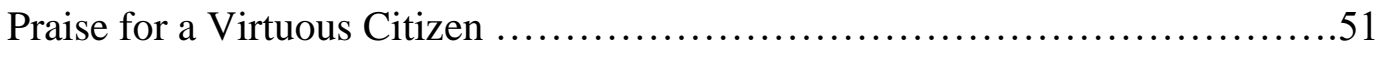

V. PATERNAL TYRANNY: THE CLOISTERED LIFE OF ARCANGELA





Influence Outside the Covent Walls ....................................61

VI. THE LEGACY OF RENAISSANCE PROTOFEMINISTS .....................66 
REFERENCES

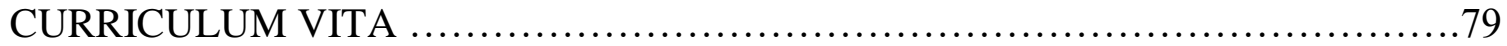




\section{INTRODUCTION}

Since Joan Kelly-Gadol first published her groundbreaking and controversial work, “Did Women Have a Renaissance," in 1977, ${ }^{1}$ historians and feminist scholars have been engaged in an academic debate over how to conceptualize women's participation in the humanist movement in Renaissance Italy. Although Kelly-Gadol's argument that Christian notions of chastity and virtue served to oppress women during the Renaissance is compelling, evolving historiography and current scholarship in sociocultural history and feminist studies suggest that notable educated women greatly contributed to the humanist dialogue of the time and acquired a degree of personal and social freedom not before granted to members of their sex. Classically-educated women such as Isotta Nogarola, Laura Cereta, Moderata Fonte, and Arcangela Tarabotti not only exemplified the academic ideals of the humanist movement, but also challenged the patriarchal social ideology and construction which served to subordinate women. The educational opportunities granted to these female humanists serve as a direct challenge to KellyGadol's theory that educated women were "merely decorative"2 and that the Renaissance further disenfranchised women.

\footnotetext{
${ }^{1}$ Renate Bridenthal and Claudia Koonz, Becoming Visible: Women in European History (Boston: Houghton Mifflin, 1997), 175-77.

${ }^{2}$ Margaret L. King and Albert Rabil, Jr., Teaching Other Voices: Women and Religion in Early Modern Europe (Chicago: University of Chicago Press, 2007), 194.
} 
While these women participated in the revival of classical learning in Italy during the Renaissance, their self-perceived contributions to humanist scholarship varied, as did their public and academic reception; both their gender and status as non-citizens heavily shaped their internal and external experiences. The support of a paternal patron, a family's social and economic capital, and a woman's marital status were often determining factors on the course and longevity of a female humanist's career. ${ }^{3}$ As young women under the authority of a father or patriarchal figure, female humanists were granted a level of social freedom, including participation in public discourse, advanced education, and prominent civic duties, which was not extended to older women of marrying age; sexual maturity marked a transitory social period, which greatly limited public and academic participation and opportunities for women in Renaissance Italy. Similarly, the extension of education beyond adolescence for women who operated outside of the patrimonial system such as nuns was not seen as a moral threat in the same way that it was for married women and widows; ${ }^{4}$ in the accepted social ideology, nuns were religiously divorced from their own sexuality and, therefore, given more social latitude. While humanism theoretically advocated for the inclusion of women into the world of classical academia, it did not transcend patriarchal ideology and religious dogma. The social value of chastity and Christian virtue did not, as Kelly-Gadol suggested, systematically thwart women's social progress, but it did greatly influence

\footnotetext{
${ }^{3}$ Virginia Cox, Women's Writing in Italy, 1400-1650 (Baltimore: Johns Hopkins University Press, 2008), 6.

${ }^{4}$ Christine Contrada, "The Civic Virtue of Women in Quattrocento Florence," (PhD diss., State University of New York at Stony Brook, 2010): 187.
} 
both the academic and social reception of learned female humanists during the Italian Renaissance. $^{5}$

This thesis explores the opportunities afforded to and limitations imposed upon female humanists in Renaissance Italy by examining the intellectual and social responses to four notable learned women: Isotta Nogarola, an unmarried Veronese who embraced celibacy in exchange for a life of study; Laura Cereta, an outspoken, married Brescian, who openly criticized the frivolity of her gender; Moderata Fonte, a Venetian wife and mother, whose feminist defense of women celebrated female friendship and intellect; and Arcangela Tarabotti, a Venetian nun, who engaged in religious and political discourses with esteemed male scholars of her time. This investigation demonstrates the connection between a female humanist's life of scholarship and her place in the patriarchal order, arguing that a learned woman's academic and social reception was dependent upon her willingness to adhere to patriarchal ideology and conform to traditional prescriptions of femininity.

At the turn of the twentieth century, prominent Renaissance historians such as Will Durant argued that the Renaissance was a time of social, intellectual, and economic awakening for both men and women in Western Europe. ${ }^{6}$ Subsequently, Mary Beard, in her 1946 work, Women as Force in History: A Study in Traditions and Realities, expanded on Durant's premise and argued that women and men benefitted equally from the Renaissance. ${ }^{7}$ In 1977, however, Joan Kelly-Gadol's aforementioned work presented

\footnotetext{
${ }^{5}$ Bridenthal and Koonz, Becoming Visible, 177-80.

${ }^{6}$ Will Durant, The Renaissance: A History of Civilization in Italy from 1304-1576, 581, as cited in Melinda K. Blade, Education of Italian Renaissance Women (Mesquite: Ide House, 1983), 18.

${ }^{7}$ Joseph R. Mitchell and Helen Buss Mitchell, Taking Sides: Clashing Views on Controversial Issues in Western Civilization, $1^{\text {st }}$ ed. (Guilford: Dushkin/McGraw-Hill, 2000), 123.
} 
a challenge to both past historiography on Renaissance study as it applied to women, such as Durant and Beard's, and traditional Renaissance periodization, effectively igniting a scholarly debate on both fronts. While Durant's contention that upper-class women received "equal scholastic freedom with their male counterparts" overestimated the humanist movement's impact on women, inaccurately generalizing that all women from the upper strata of society were classically educated in a manner equal to that of men, ${ }^{8}$ Kelly-Gadol's claim that the Italian Renaissance did not produce a more progressive model for female education underappreciated evidence that upper-class women were more educated than their medieval predecessors. As more recent scholarship has reasonably proven, both extreme historical perspectives are flawed; while the structure and content of Italian Renaissance women's education may have varied depending upon their tutelage and location, the conciliatory position that there was a model for female humanists' education which benefitted select women can safely be made. No longer is it, as Melinda Blade stated, "a generally accepted fact that [there was] .... Male-female scholastic equality among the upper class youth" or, as she continues, that, "historians are in general accord [that] ... fathers played no role at all" in the education of their daughters. ${ }^{9}$ Works from scholars such as Patricia Labalme and Constance Jordan successfully demonstrated, ${ }^{10}$ by analyzing protofeminist rhetoric in Renaissance works, that historians can more fully conceptualize women's access to education and their participation in the humanist movement without swinging to either

\footnotetext{
8 Ibid., 29.

${ }^{9}$ Blade, Education of Italian Renaissance Women, 29. Blade heavily quotes the work of H.J. Mozans (1851-1920) to support her argument that mothers and not fathers played the primary role in the education of girls within the domestic context.

${ }^{10}$ Patricia Labalme, "Venetian Women on Women: Three Early Modern Feminists," Archivio Veneto, 117 (1981): 81-109; Constance Jordan, Renaissance Feminism: Literary Texts and Political Models (Ithaca: Cornell University Press, 1991).
} 
side of the "Did Women Have a Renaissance?" pendulum. Furthermore, asking if "women" had a Renaissance is not only problematic because the term "renaissance" is used both to denote historical periodization and social regeneration ${ }^{11}$, but the question also obscures the variety of female experiences by implying that women are a monolithic, homogeneous group. Thus, recent historiography implores contemporary scholars to answer more probing questions.

Renaissance scholarship from the last two decades, in large part the product of the rising popularity of cultural history and the contribution of feminist studies, has challenged the outmoded narrative that Italian Renaissance women educated in the humanist tradition were social anomalies who sat on the periphery of academic life. A number of prominent scholars have published compelling works that not only dispute overly-negative assessments of learned Renaissance women as marginalized or exceptional, but have contextualized women's participation within humanism in a less dichotomous, binary manner. Historian Margaret King, perhaps the most prolific contemporary writer in the field, has published numerous books and articles on the Renaissance, many of which focus on the lives of select Italian female humanists and the supportive relationship they enjoyed during early adolescence with their untraditional fathers and male patrons. The combined works of prominent historians such as Albert Rabil, Letizia Panizza, Janet Smarr, Margaret Rosenthal, Diane Maury Robin, and Virginia Cox similarly contextualize learned women within the center of the Italian

\footnotetext{
${ }^{11}$ Guido Ruggiero, The Renaissance in Italy: A Social and Cultural History of the Rinascimento (New York: Cambridge University Press, 2014), 12-3. Ruggiero argues that the term "renaissance" is problematically based on the French re-naissance, which is both anachronistic and culturally bound.
} 
humanist movement and highlight the contributions notable published female authors made to Renaissance literature.

Further demonstrating that learned girls were not transgressive figures, whom society deemed as unfeminine outcasts, Sarah Ross's book, The Birth of Feminism: Women as Intellect in Renaissance Italy and England, portrays young female humanists as feminist academics molded under paternal tutelage. ${ }^{12}$ Ross claims that under the authority of humanist fathers, young women participated in the intellectual discourses of their time in a meaningful way; in doing so, they advocated for women's intellectual and social equality. This thesis builds on Ross's contention that "the intellectual family," in part, provided the foundational structure for women's participation within humanism, which as she argues, was the catalyst for the modern feminist movement. While Ross's model of "the intellectual family" provides a solid foundation for an investigation of Italian humanist training in childhood, her analysis, however, is narrowly focused on the father-daughter relationship of tutelage; fathers and male patrons often served different roles in adult women's lives and, additionally, learned women's continued participation in humanism and their relationships with male patrons became more complex and socially tenuous once they passed the age of sexual maturity. This investigation, therefore, in large part expands upon Ross's work by arguing that adult women's willingness to subscribe to the patriarchal order influenced the success and longevity of their humanist careers as much as the support of paternal figures within intellectual families.

\footnotetext{
${ }^{12}$ Sarah G. Ross, The Birth of Feminism: Woman as Intellect in Renaissance Italy and England (Cambridge: Harvard University Pres, 2009).
} 
Although this thesis acknowledges the immeasurable value of previous historical and feminist study, it also contends that scholars have yet to explicitly explore the relationship between the longevity of an adult female humanist's career, the public and academic reception to her academic vocation and discourses, and her place within the patriarchal system. By focusing solely on either young women as protégés of humanist fathers or mature women as social outcasts, previous studies have failed to fully analyze the relationship between academic legitimacy and paternal or patriarchal patronage in adulthood. While scholarship over the last two decades has more thoroughly studied the supportive role fathers played in nurturing their daughters' humanist education, thereby challenging Margaret King's claim that "male hostility to female learning [was] widespread," ${ }^{13}$ a strict adherence to the father-daughter model too narrowly defines the methodological parameters by which the reception of Italian female humanists who moved away from the security of patriarchal patronage can be studied.

Similarly, the definition of patriarchal patronage must be expanded beyond Ross's model of "the intellectual family" to include male figures other than fathers who provided legitimacy to women's work past the age of sexual maturity. While young female scholars did, "capitalize upon the cultural legitimacy that patriarchal sanction - or its representation - afforded," 14 simply analyzing the scholastic life and opportunities of Italian female humanists within the father-daughter paradigm of patronage methodologically bounds historians to a limited social and economic group; questions which focus on Renaissance periodization or women's access to education within the family model only move scholarship so far. I suggest that historians question why and

\footnotetext{
${ }^{13}$ Margaret L. King, Women of the Renaissance (Chicago: University of Chicago Press, 1991), 181.

${ }^{14}$ Ross, The Birth of Feminism, 2.
} 
how the transition from childhood to adulthood profoundly affected women's educational activity, why the role of a patriarchal patron - which included fathers, husbands, extended family, and the Catholic Church - ensured some degree of social legitimacy to female academic work, and how adult women meaningfully participated in academic circles when society deemed their endeavors unfeminine. The argument advanced in this thesis, therefore, hinges on these questions and demonstrates that there is a connection between a woman's sexual maturity, her adult life of humanist scholarship, and her willingness to adhere to traditional prescriptions of femininity and patriarchal ideology. Many women did have a "renaissance" as it has been traditionally defined in that they participated in the return to classical learning and culture, ${ }^{15}$ but the degree to which they engaged in humanist scholarship in adulthood varied; when they emerged from childhood sexually mature, they were often forced to strategically navigate their academic life apart from the security of paternal legitimacy. Women who maintained some measure of patriarchal support or more willingly adhered to social prescriptions of femininity were more positively regarded.

The case studies chosen for this investigation all illustrate the connection between a learned woman's adherence to social and feminine ideology and her adult life as a humanist scholar. Beginning with Isotta Nogarola, who is referred to as one of the first female humanists, and moving through to the life of seventeenth-century nun Arcangela Tarabotti, the cumulative lifespans of the women chosen cover over two hundred years. The selection size of the study has been limited in order to allow for an in-depth analysis of each figure and the integration of primary source material; excerpts from the women's

\footnotetext{
${ }^{15}$ Ruggiero, The Renaissance in Italy, 12-3.
} 
most notable work and correspondence with male humanists will be offered as support for the overall argument. The women in these case studies have also been selected because of their distinct social and marital position: Isotta Nogarola chose to remain unmarried; Laura Cereta was married at a very early age, but was quickly widowed; Moderata Fonte was married at a later age and was the mother of four children; and Arcangela Tarabotti was a cloistered nun sent to live in a convent at an early age against her will. These women represent a variety of academic tutelage, paternal involvement, social backgrounds, marital choices, and genres of work. Their diversity supports my broad argument regarding the longevity and public reception of women's humanist careers based on their place within the patriarchal order and not simply their education under "the intellectual family" model. As most Italian female humanists arose out of wealthy Northern Italian families, geographic and economic variability was not a significant factor in the selection process.

While the case selections are limited, the small sample size is intentional and not a validation of claims that learned women were "exceptional," which was a designation likely assigned by men and not the self-assessment of women. Generalities regarding these select female humanists' social and academic experiences and reception can be reasonably extended to a wider group of female humanist contemporaries. This small biographical collection, therefore, is not intended to be exhaustive, but simply meant to challenge the notion that learned women were socially marginalized once past the age of sexual maturity and advance the argument that male legitimization was key to their reception and continued engagement in humanism. By taking a microhistorical methodological approach of sorts and looking at women who have historically been 
considered anomalous, this thesis challenges the notion of exceptionality without underappreciating individuals' circumstances. While the move from micro to macro can be methodologically problematic if generalizations are too liberally applied or the historian's narrative voice too pronounced, this thesis attempts to avoid those pitfalls by relying on the subjects' and their contemporaries' writings whenever possible. The investigation of Renaissance humanism and the educational opportunities the movement provided for women in Part I contextualizes the social and academic milieu of the notable women presented in the case studies. As a whole, this thesis illustrates that the advent of humanism in Renaissance Italy did grant women greater educational opportunities than those afforded to their predecessors and contends that the patriarchal construction of society, and more importantly, a female humanist's willingness to adhere to feminine ideology, determined the course of her adult academic life and public reception. 


\section{THE RENAISSANCE HUMANIST MOVEMENT}

At the turn of the fourteenth century, while Italy was slowly recovering from the devastating effects of the Bubonic Plague, an academic dialogue emerged between notable secular and theological scholars regarding the nature of man and the universe. Believing that the world had slowly declined since antiquity and that classical learning had been abandoned in the Middle Ages, these intellectuals began to look to Greek and Roman texts and political discourses as guides to social restoration; humanity could be better understood, they believed, by looking back to a historical period of prosperity and strong civic virtue. ${ }^{16}$ Literary scholars such as Petrarch (1304-1374) rejected the medieval intellectual and Scholastic traditions which focused primarily on religious themes and instead advocated for an individualized studia humanitatis. This path to knowledge through a curriculum of grammar, rhetoric, history, poetry, philosophy, and classical thought marked the renewed interest in the accomplishments of human endeavor and advocated for the institution of social reform through language and learning. ${ }^{17}$ By the beginning of the fifteenth century, this method of study known as humanism became the dominant intellectual movement in Renaissance Italy.

\footnotetext{
${ }^{16}$ J. Stephen Edwards, "A Woman is Wise: The Influence of Civic and Christian Humanism on the Education of Women in Northern Italy and England During the Renaissance," (PhD diss., 2002): 1. ${ }^{17}$ Joan Gibson, "Educating for Silence: Renaissance Women and the Language Arts," Hypatia 4, no. 1 (1989): 11.
} 
Quattrocento humanists in northern Italian city-states were particularly concerned with the notion of civic humanism, a program of education which served the needs of the state and guided virtuous civic action. ${ }^{18}$ Early humanists such as Petrarch and Bracciolini (1380-1459) read and translated classical Greek and Roman texts searching for guidance on how to create a politically and socially enlightened society. The study of political discourse, classical oratorical practices, and formal rhetoric were based on the early humanists' theory that the rational exchange of ideas between citizens served the public good and brought favor upon their city; civic humanism was the product of a virtuous society.

The studia humanitatis of classical language, philosophy, and rhetoric was revived to cultivate moral character and encourage civil service: the more knowledgeable the person, the more virtuous the citizen. ${ }^{19}$ Based on this argument, humanists believed a classical education would strengthen social virtue. Consequently, humanist scholars were presented with a theoretical dilemma: could women be virtuous and fulfill their civic duty, which included raising civically-minded sons, if they lacked an education? Furthermore, could women provide the proper social and academic edification for their sons if their participation in the vita activa was greatly restricted? As Sarah Ross points out, "emphasizing not only Christian morality but classical notions of fortitude and accomplishment, the humanist redefinition of virtue left a fruitful ambiguity at the center of its educational program ... if men and women should be 'virtuous,' and if education presented a principal means to that end, then women should be educated." ${ }^{20}$ She further

\footnotetext{
${ }^{18}$ Edwards "A Woman is Wise," 1.

${ }^{19}$ Blade, Education of Italian Renaissance Women, 18.

${ }^{20}$ Ross, The Birth of Feminism, 4.
} 
contends that the conflict between theory and practice revealed scholars' deep division over this issue.

In the Aristotelian tradition, women were assumed to be biologically and rationally inferior to men. Similarly, medieval society generally embraced the notion of female logical and intellectual inferiority. ${ }^{21}$ Both Scholastic philosophy and medieval social ideology were built upon a misogynistic intellectual tradition which systematically excluded women, and although humanist logic theoretically challenged this assumption by acknowledging that both men and women were capable of reason, scholars such as Erasmus (1466-1536) maintained that women were capricious and shallow-minded. ${ }^{22}$ While Italian society transitioned from the medieval value of the vita contemplativa, or contemplative life, to the Renaissance notion of the vita activa, or active civic life, women were still largely excluded from civic discourse as a result of their status as subordinate, non-citizens. It was primarily because of women's role in the edification of future male citizens that like-minded humanists began to slowly concede that there was a civic value in the basic education of women.

Other humanist scholars such as Leonardo Bruni (1370-1444), Juan Luis Vives (1493-1540), and Sir Thomas More (1478-1535), who himself educated his own daughter in the humanist tradition, advocated for the education of women as a means of promoting civic virtue and strengthening the patrimonial system. ${ }^{23}$ A number of humanist treatises on women's education and their role within society, such as Bruni's On Studies and Letters (ca. 1423-1426), challenged the misogynistic Aristotelian tradition and helped

\footnotetext{
${ }^{21}$ Cox, Women's Writings in Italy, xv.

${ }^{22}$ Edwards, "A Woman is Wise," 7.

${ }^{23}$ Ibid., 2.
} 
construct a system in which women were recipients of a humanist education. ${ }^{24}$ Vives believed that, "learning was pure and worthwhile only if it led to virtue ... [and] by using one's intelligence to weigh the nature and value of each experience, one determines the course to follow and the course to avoid." ${ }^{25}$ As such, an educated woman could not only serve the greater good of her city, but could better avoid sin and uphold Christian society. $^{26}$

While it would be an overstatement to assert that such scholars viewed women as intellectual equals who were entitled to an education identical to that provided to men, they did advocate for a program of study which encouraged women to transcend their feeble character and emulate superior, masculine sensibilities. Treatises generally reconciled the notion of female education with traditional patriarchal ideology by emphasizing that learned women better adhered to stereotypical female virtues such as chastity and obedience; education strengthened a woman's character, which in turn, stabilized the social order. ${ }^{27}$ Knowledge translated to social power, righteousness, and prestige, so for civically-minded Italian cities, the education of women ultimately served the needs of the state. The rhetorical argument that female education strengthened society and, by extension, civic virtue, underscored the goal of humanism. In Northern republics such as Venice, Florence, and Siena, the impetus was even greater to educate women than it was in Southern principalities because they played a central role in the tutelage of future male citizens.

\footnotetext{
${ }^{24}$ Leticia Panizza, introduction to Paternal Tyranny, by Arcangela Tarabotti (Chicago: University of Chicago Press, 2007), xxi.

${ }^{25}$ Blade, Education of Italian Renaissance Women, 49.

${ }^{26}$ Cox, Women's Writings in Italy, 48.

${ }^{27}$ Gibson, "Educating for Silence," 10.
} 
Many influential humanists who advocated for female education such as Bruni believed that a young girl's studies should in most ways mirror that of a boy's: the study of classical languages, history, grammar, philosophy, and poetry all constructed both boys' and girls' classical education. Bruni, like Vives and Erasmus, stated, however, that it was of no value to provide a girl instruction in oration or rhetoric, for it was not decorous for women to speak in public or participate in communal affairs. ${ }^{28}$ The omission of logic and rhetoric from girls' humanist curriculum reflected the patriarchal ideology that public speaking was the realm of men and that it was immodest for women to be overly visible in society. ${ }^{29}$ Women with a voice had power, and thus, were seen as a social and political threat.

Only a curriculum of study that would combat idleness, preserve chastity, and improve upon female nature was, therefore, an appropriate addition to a girl's humanist education. ${ }^{30}$ As Erasmus claimed, upper-class parents should instruct their daughters in subjects such as history and grammar, "for study busies the whole soul ... [and] is not only a weapon against idleness, but also a means of impressing the best precepts upon a girl's mind and leading to her virtue .... [there is] nothing more intractable than ignorance." 31 It was the parents' duty and, more specifically, the father's civic and religious charge, to raise chaste, virtuous, and modest daughters; by extension, providing a humanist education to their daughters was key to parents' fulfillment of civic service and brought a family honor, increased social status, and improved marriage prospects.

\footnotetext{
${ }^{28}$ Margaret L. King and Albert Rabil, Jr., Her Immaculate Hand: Selected Works by and About the Women Humanists of Quattrocento Italy (Binghamton: Medieval and Renaissance Texts and Studies, 1983 ), 15. ${ }^{29}$ Gibson, "Educating for Silence," 12.

${ }^{30}$ Letizia Panizza, “The Fifteenth Century: Humanism," in A History of Women 's Writing in Italy, edited by Letizia Panizza and Sharon Wood (Cambridge: Cambridge University Press, 2000), 25.

${ }^{31}$ Erasmus, Christiani matrimonii institution, as cited in King, Women of the Renaissance, 181.
} 


\section{The Humanist Education of Women}

The humanist model for educating women in classical literature, history, and Scholastic philosophy within the domestic context emerged in the early fifteenth century and provided girls with opportunities previously only extended to boys. Although earlier examples of women who were educated in the domestic sphere under the tutelage of fathers or male relatives exist, the instruction they received in arithmetic and reading was compulsory in comparison to humanism's comprehensive, liberal education in the antiquities. ${ }^{32}$ Early humanists almost always arose out of noble families or the uppermiddle class and were often tutored at home by older siblings or a humanist father. ${ }^{33} \mathrm{~A}$ family's social position, public and political influence, and the father's profession were often directive forces in the education of both female and male children; a girl's social and family background had important implications for the course of her academic career. ${ }^{34}$ Although women who received a classical education were undoubtedly in the minority, there were humanist fathers who provided the impetus for their daughters' schooling and fostered their intellectual pursuits. ${ }^{35}$ Young girls whose fathers greatly valued education were taught Latin alongside their male siblings and were granted a significant degree of intellectual and social freedom.

As Sarah Ross argues, "the intellectual family" legitimized the first female humanists: learned fathers provided for the classical education of their daughters, which contributed to the family's intellectual honor and social capital. ${ }^{36}$ Highly-educated

\footnotetext{
${ }^{32}$ Margaret King, "Thwarted Ambitions: Six Learned Women of the Italian Renaissance," Soundings: An Interdisciplinary Journal 59, no. 3 (Fall 1976): 282.

${ }^{33}$ Panizza, "The Fifteenth Century," 25.

${ }^{34}$ Cox, Women's Writings in Italy, 6.

${ }^{35}$ King, Women of the Renaissance, 185.

${ }^{36}$ Ross, The Birth of Feminism, 3-9.
} 
daughters were seen as their fathers' intellectual protégées, and although male humanists generally excluded women from public activity, very young girls could give public orations if the intent was to bring virtue and glory to either their family or city. ${ }^{37}$ For instance, as young girls, both Isotta Nogarola and Laura Cereta were praised as erudite rhetoricians and allowed a public platform for their orations; both were regarded as famous adolescent prodigies within northern Italian humanist circles. Some young female scholars such as Cereta were seen as "walking illustrations of their fathers' pedagogical talents" and received an education, in part, to inflate the intellectual egos of their fathers and increase the social capital of their lineage. ${ }^{38}$

While it is clear that the family, and most notably the father, often played a central role in the formation of a young girl's education, it is critical to note that "the intellectual family" was a product of the domestic nature of Renaissance education; women were not given opportunities for education outside of the domestic sphere. The domestic nature of humanist training also effectively set up a system in which female education was only legitimate when confined to the domestic sphere under the supervision of a patriarch. As the case studies discussed here illustrate, paternal or patriarchal oversight was critical to academic legitimacy and social acceptance.

For many female humanists, there was a perilous transitory period between their childhood academic training and their role as mature women in society. While I agree with scholars such as Virginia Cox who argue that, "It is not by any means the case that ... there was simply no place for the learned woman in the social environment of

\footnotetext{
${ }^{37}$ Margaret L. King, Renaissance Humanism: An Anthology of Sources (Indianapolis: Hack Publishing Company, 2014), 264.

${ }^{38}$ Cox, Women's Writings in Italy, 6.
} 
'Renaissance Italy' nor that learned women were universally perceived as 'threats to the natural and social order' or 'aroused fear and anger in male contemporaries," ${ }^{39}$ there does seem to be sufficient historical evidence to suggest that the freedom of youthful study did not fully extend into adulthood and that adult life of study was more socially perilous. Young women were not yet burdened by the pressures of marriage and motherhood and, as such, were permitted and encouraged to devote time to academic pursuits; unfortunately, the notion of "learned virtue" and professional scholarship as a vocation infrequently applied to adult women. Women who forged successful adult careers did so by securing patriarchal support, which legitimized their continued engagement in humanism. Outside of the tutelage or direction of a patriarchal figure, very few learned women continued with their studies and produced substantive works after the narrow window of youth came to a close. ${ }^{40}$

For most humanist women, two life choices existed: the life of marriage and motherhood, which often meant the abandonment of study, but provided for some level of social participation, or life in a convent, which allowed for continued education, but required a withdrawal from the world and often resulted in oppressive solitude, ${ }^{41}$ as Arcangela Tarabotti's works explain, this cloistered solitude was often determined by a family's financial circumstance and mandated by a father against his daughter's will. Although some women successfully established a partial means to continue their studies within the confines of patriarchal society, most who attempted to do so were vilified for

\footnotetext{
${ }^{39}$ Ibid., 7.

${ }^{40}$ Margaret L. King, "Book-Lined Cells: Women and Humanism In The Early Italian Renaissance," in Beyond Their Sex: Learned Women of the European Past, ed. Patricia Labalme (New York: New York University Press, 1980), 69.

${ }^{41}$ Ibid.
} 
going "beyond their sex" ${ }^{42}$ Virginia Cox argues that, "Female scholars also generated a notable degree of social opprobrium, especially when they came to make the transition from precocious adolescents to adult, sexual women. Social convention, it is claimed, appeared to demand that women set aside their intellectual ambitions on marriage." ${ }^{\prime 3}$ Woman who revolted against the patriarchal ideology that female education was a luxury of youth were often either the victims of harsh criticism, like Laura Cereta, or were psychologically and socially wounded by accusations of immorality and unchastity, like Isotta Nogarola. The society which once heralded the child prodigy as glorious now saw the learned woman as threatening. ${ }^{44}$

While the patriarchal social order in large part determined the opportunities afforded to both women and men, it is clear that humanism did catalyze for a shift in ideology regarding the education of girls. Rationalizing the extension of a classical education to girls as a means of civic service, male humanists began to engage young women in a liberal model of education and fostered their intellectual pursuits. While Margaret King is accurate in asserting that in general, "women humanists did not achieve great status in the world of humanism or recognition of intellectual parity of men," ${ }^{45}$ it is important that scholarship not reduce all women to a singular experience; the selfperception and public reception of learned humanist men is not discussed in a monolithic fashion, nor are their contributions to history diminished because of their sex. What these case studies reveal is that while gender did shape women's access to education and social latitude, an individual woman's public and academic acceptance as humanist scholar was

\footnotetext{
${ }^{42}$ Ross, The Birth of Feminism, 282.

${ }^{43}$ Cox, Women's Writings in Italy, 6.

${ }^{44}$ Contrada, "The Civic Virtue," 187.

${ }^{45}$ King, Her Immaculate Hand, 28.
} 
very much tied to her unique circumstance, willingness to adhere to patriarchal ideology, and her level of conformity to traditional prescriptions of femininity. Adult female humanists were not immediately, inevitably marginalized after reaching the age of sexual maturity; however, they did have to strategically secure some measure of patriarchal patronage to continue their life of scholarship. 


\section{BOOK-LINED CELL: THE SOLITARY LIFE OF ISOTTA NOGAROLA}

Before humanism emerged as a prominent intellectual movement in Renaissance Italy during the early fifteenth century, the overwhelming majority of women outside of royal courts only received a domestic education and little, if any, formal schooling. Even the education provided to the daughters of the upper-class nobility during the Middle Ages was compulsory and heavily influenced by the patriarchal Scholastic tradition which viewed women as intellectually inferior and unfit to engage in formal academic instruction. Although some early fifteenth-century male humanists slowly began to challenge medieval notions of female capability, early female devotees to the humanist movement such as Isotta Nogarola (1418-1466) fought against an intellectual tradition which systemically excluded them from learning based on misogynistic ideology. Even prominent humanist Leonardo Bruni's stated, "For why exhaust a woman with the concerns of status and epicheremata, and ... [the] difficulties of rhetorical art, when she will never be seen in the forum ... For if a woman throws her arms around whilst speaking, or if she increases the volume of her speech with greater forcefulness, she will appear threateningly insane and requiring restraint." ${ }^{46}$ Forced to navigate their academic careers in a world which valued chastity

\footnotetext{
${ }^{46}$ H. Baron (ed.), Leonardo Bruni Aretino Humanistische-Philosophische Schriften mit einer Chronologie seiner Werke und Briefe (Leipzig, 1928), 11-2, translated in Lisa Jardine, "Isotta Nogarola: Women Humanists - Education for What?" in The Italian Renaissance, ed. Paula Findlen (Malden: Blackwell Publishing, 2002), 277.
} 
and passivity as the most sacred, extolled female virtues, young female scholars' academic ambitions were often thwarted by the realities of patriarchal society. For Isotta Nogarola, in particular, endeavoring to engage in academic pursuits after adolescence and outside of a patriarch's control proved emotionally and socially destructive. To continue her life of intense humanist scholarship into adulthood, she was forced to relinquish her idealistic desire for social autonomy and comply with traditional prescriptions of femininity.

Isotta Nogarola was one of the first woman humanists to emerge out of Italy during the Renaissance. Known to modern scholars as the most famous female intellectual of her time, Nogarola's contemporary reception in her birthplace, Verona, and in humanist circles throughout Northern Italy, waivered during her academic career. Under the tutelage of her father Leonardo before his death, her mother Bianca, and tutor Martino Pizzoni, a humanist scholar from Guarino Guarini’s prestigious academy, Nogarola and her siblings were provided with a classical education as youth and became admired members of Veronese society. ${ }^{47}$ As an adolescent, Nogarola was praised throughout humanist circles and wrote extensively; twenty-four letters written by Nogarola, and twenty-seven written to her have survived and point to her enthusiasm for study, her keen intelligence, her mastery of classical language and philosophy, and the open dialogue she maintained with prominent male scholars. ${ }^{48}$ In a 1436 letter to Jacopo

\footnotetext{
${ }^{47}$ Jardine, "Isotta Nogarola," 278; Margaret L. King and Diana Maury Robin, introduction to Complete Writings: Letterbook, Dialogue of Adam and Eve, Orations, by Isotta Nogarola (Chicago: University of Chicago Press, 2014), 3-4.

${ }^{48}$ Margaret L. King, "Petrarch, Self-Conscious Self, and the First Woman Humanists," Journal of Medieval and Early Modern Studies 35, no. 3 (2005): 541-42.
} 
Foscari, son of the doge of Venice, Guarino himself complimented Nogarola by writing the following:

Oh the glory indeed of our State and our Age! Oh how rare a bird upon earth, like nothing so much as a black swan! If earlier ages had borne these proven virgins, with how many verses would their praises have been sung, how many deserved praises by truly unstinting authors would have consigned them to immortality ... these so modest, so noble, so erudite, so eloquent women. ${ }^{49}$

Emphasizing that the primary intention of humanism was to increase civic value, Guarino touted the Nogarola sisters' virginal purity as virtuous and their humanist training as successful, for the young girls brought glory to their city of Verona. Similarly, at Nogarola's brother's request for assistance with her education, Lauro Quirini, a pupil of Guarino's, also celebrated the young female scholar by saying, "For you, who have been thoroughly instructed in the most polished and excellent art of discourse, and who find elegance in orating and suavity of speech comes naturally, you are able of your own accord to expect the great perfection in eloquent speech." ${ }^{, 50}$ As such, Nogarola and her accomplishments as a young intellectual protégé of the Veronese humanist tradition were placed within a civic context and legitimized by her association with prominent patriarchal figures. Unfortunately, although the letters she composed and circulated as a young scholar established her place in the intellectual community, they ultimately opened Nogarola up to charges of unchastity and lewdness as she matured into a sexually-viable woman. ${ }^{51}$ Once she reached the age of sexual maturity and marriageability, the confidence and initiative she displayed as an adolescent were interpreted as unfeminine and an insult to masculine propriety.

\footnotetext{
${ }^{49}$ E. Abel, Isotae Nogarolae Veronesis opera quae supersunt omnia (Budapest, 1886) I, 58-9, translated in Jardine, "Isotta Nogarola," 281.

${ }^{50}$ Ibid., 274.

${ }^{51}$ King, Women of Renaissance, 196.
} 


\section{A Woman in A Man's World}

After she reached the age of sexually maturity and relocated to Venice, Nogarola's engagement with humanism was no longer legitimized by her father or her family's social connections. While Nogarola was lauded as a child prodigy within Veronese society - her acceptance a product of her young age, father's status, and her connection with well-regarded male humanists - both Venetian scholars and her former Veronese academic sponsors began to view her ambitious actions as an affront to feminine propriety; initiating correspondences with men was acceptable when she was under paternal authority, but after she reached the age of sexual maturity, it became socially dangerous to directly communicate with men. At this point, Nogarola was seen within her society as an impudent and indecorous unmarried woman who had committed a serious social transgression by contacting male scholars and soliciting admittance into their intellectual circles. ${ }^{52}$ In a response to Nogarola's repeated requests for correspondence, Guarino wrote, "I know that your mind, adorned with knowledge, was excellent, yet up to now I believed and trusted that your soul was manly, and that brave and unvanquished you could face all adversities. But now you seem so humbled, so abject, and so truly a woman, that you demonstrate none of the estimable qualities that I thought you possessed." 53 Although Guarino promised to come to Nogarola's defense within the same correspondence, her arrogance and impropriety in the pursuit of a career of humanist study over marriage, coupled with his earlier rejection of her infamous and circulated solicitations for communication, publicly shamed Nogarola and served as

\footnotetext{
52 Ibid.

${ }^{53}$ King, "Thwarted Ambitions," 285.
} 
evidence of her immorality. ${ }^{54}$ Especially for a woman of Nogarola's social position, it was inconceivable that she would forego marriage, which was socially and economically prudent, for a life of study. ${ }^{55}$ The ramifications of her decision not to marry once she reached her socially-determined prime - not to conform to conventional prescriptions of femininity - were profound.

Eloquent, ambitious women who wanted to remain single like Nogarola had no place in traditional, patriarchal Renaissance society. Nogarola's social visibility not only opened her up to the envy and hostility of men who saw her as an aberration of female nature, but of women who viewed Nogarola's actions as equally improper. ${ }^{56}$ Although early in Nogarola's career, she criticized the disparaged position of women in society and advocated for a learned woman's right to devote her life to the pursuit of academic study, her oppressed contemporaries did not view her as an ally. ${ }^{57}$ Unfortunately, Nogarola's outspoken nature was just as offensive to woman as men; eloquence was valued for its civic function, and because women were expected to be passive and quiet, their virtue was in the domestic rather than the public realm. ${ }^{58}$ In Venice, where women were typically isolated to protect their virtue, Nogarola was criticized by members of her own sex for exhibiting pretentious and vulgar behavior, and Nogarola herself wrote that, "I am ridiculed throughout the city, those of my own condition deride me. I am attacked on all sides." ${ }^{59}$ She attempted to defend her actions by writing to her detractors, "Do not hold it

\footnotetext{
${ }^{54}$ King and Rabil, Her Immaculate Hand, 813.

${ }^{55}$ King and Robin, Complete Writings, 6.

${ }^{56}$ King, "Book-Lined Cells," 73.

${ }^{57}$ Contrada, "The Civic Virtue," 81, 150.

${ }^{58}$ Luka Boršić and Ivana Skuhala Karasman, "Isotta Nogarola - the Beginning of Gender Equality in Europe," Monist 98, no. 1 (2015): 45.

${ }^{59}$ Abel I, 80-1 translated in Jardine, "Isotta Nogarola," 284; Margaret L. King, "The Religious Retreat of Isotta Nogarola (1418-1466): Sexism and Its Consequences in the Fifteenth Century," Signs 3, no. 4 (1978): 809.
} 
against me, if I have transgressed those rules of silence especially imposed on women, and seem scarcely to have read that precept of Vergerio's, which warns against encouraging articulateness in the young, since in plentiful speech there is always that which may be censured. ${ }^{\prime 60}$ Although Nogarola protested the injustice of the public's criticism, she also dejectedly lamented that, "there are already so many women in the world! Why then was I born a woman, to be scorned ... for I am jeered at through the city, my sex mocks me, nowhere do I have a restful resting place." ${ }^{, 1}$ While she desperately wanted to find approval within humanist circles, she was painfully aware that both men and women saw her as socially indecorous because she no longer fit neatly into the patriarchal order. As the criticisms of Nogarola reflect, highly-educated women who chose study over marriage sinfully endeavored to transgress their sex according to the patriarchal ideology, which both men and women subscribed to, and were, therefore, socially ostracized. ${ }^{62}$

In 1439, Nogarola was the target of a vicious, public attack on both her character and her moral fortitude. An anonymous letter, most likely written by an enemy of her family or jealous scholar, accused Nogarola of obscene sexual and incestuous behavior. ${ }^{63}$ Of Nogarola's behavior, the accuser wrote:

[She], who has won such praise for her eloquence, does things which little befit her erudition and reputation - although this saying of many wise men I hold to be true: that an eloquent woman is never chaste; and the behavior of many learned women also confirms this truth ... let me explain that before she made her body generally available for promiscuous intercourse, she had first permitted, and indeed even earnestly desire that the seal of her virginity be broken by none other

\footnotetext{
${ }^{60}$ Abel I, 77 translated in Jardine, "Isotta Nogarola," 283.

${ }^{61}$ King, "The Religious Retreat of Isotta Nogarola," 810.

${ }^{62}$ Contrada, "The Civic Virtue," 79.

${ }^{63}$ King, "The Religious Retreat of Isotta Nogarola," 809.
} 
than her brother ... she, who sets herself no limit to this filthy lust, dares to engage so deeply in the finest literary studies. ${ }^{64}$

As evident in the author's mention of both her chastity and studies, Nogarola's immorality was directly tied to her choice to remain unmarried and devote her life to scholarship. Correspondents sympathetic to Nogarola's situation, like Guarini, urged Nogarola to "become a man" and dissociate herself from her female nature by embracing chastity and solitude as a model for scholarship and by being "joyful, gay, radiant, magnanimous, and constant [to] create a man within the woman, so that [she] may laugh at whatever may occur." 65 He continued, saying, "It was not proper ... in my judgment, that a virgin [female scholar] should consider marriage, nor even think about that liberty of lascivious morals, that libidinous cohabitation." 66 Others similarly suggested that in order to pursue a life of study, she would have to cease to be a woman and focus only on her studies in solitude like esteemed male scholars because her academic success was undermined by the frailty of her of female nature ${ }^{67}$ Humiliated, Nogarola realized that a life of chastity was the only defense against criticism and the encumbrances of marriage, so she heeded their advice and retreated from society. By refusing to prescribe to traditional gender norms and notions of femininity, Nogarola had challenged the patriarchal order, and her actions were not only disreputable, but socially subversive. She had been painfully reminded that virginity and silence were her only valuable social credentials. $^{68}$

\footnotetext{
${ }^{64}$ King, "Book-Lined Cells," 70.

${ }^{65}$ King, "The Religious Retreat of Isotta Nogarola," 808.

${ }^{66}$ Abel II, 98:14-17 translated in King, "Thwarted Ambitions," 287.

${ }^{67}$ Contrada, "The Civic Virtue," 187.

${ }^{68} \mathrm{King}$, Women of the Renaissance, 198.
} 


\section{The Virtue in Monastic Life}

As an unmarried woman trying to assert herself into a male world, Nogarola was condemned; as a virgin living a holy life of seclusion devoted entirely to God and study, she was applauded. Although her self-perception was markedly deflated after the public humiliation she endured, her public reception was rehabilitated when she embraced a socially-acceptable monastic lifestyle. Once a prolific writer, Nogarola was notably silent after her self-imposed retreat, which points to her resignation and her disappointment over the nonconsummation of her public academic career. ${ }^{69}$ After abandoning public life and embracing "a book-lined cell," Nogarola redirected her studies towards theology, which was viewed as a more traditional, proper subject of reflection for women. ${ }^{70}$ Although her scholarly seclusion was praised by male humanists as ideal for contemplative study and the preservation of chastity, Nogarola's letters indicate that she suffered from the extreme isolation. ${ }^{71}$ As Margaret King argues, her self-imposed exile and chastity was in ways a "defiance of the established natural order and of the learned man's attempt to constrain her energies by making her mind the prison for her body," which made it both a "source of pride and independence ... [and] an instrument of repression." 72 In Nogarola's case, the freedom to totally immerse herself in study was academically liberating, but socially isolating. After an over decade-long silence, Nogarola reached out again to a male humanist in search of intellectual stimulation, but unlike her first solicitation for engagement, this invitation was positively received

\footnotetext{
${ }^{69}$ King, "Petrarch," 543.

${ }^{70}$ Holly S. Hurlburt, “A Renaissance for Renaissance Women?” Journal of Women's History 19, no. 2 (2007): 195.

${ }^{71}$ King, "Book-Lined Cells," 76-8.

72 Ibid.,
} 
because Nogarola's reputation had been rehabilitated. By taking a self-imposed vow of chastity and, in effect, transforming herself into an asexual, holy woman, Nogarola was assuming an acceptable place in the patriarchal order. She could now garner the support of reputable patriarchal figures for her work and extend the longevity of her career without reproach.

When Nogarola reemerged in humanist circles after a decade in isolation, it was through her correspondence with Veronese governor, Ludovico Foscarini, with whom she engaged in perhaps her greatest work: an eight-year religiously-themed dialogue about the sinfulness of Adam and Eve. ${ }^{73}$ Humanist Lauro Quirini, who also exchanged letters with Nogarola, told her that as a result of her transformation, "The greatest praise is justly bestowed upon you, illustrious Isotta, since you have ... overcome your own nature. For that true virtue, which is essentially male, you have sought with singular zeal ... such as befits the whole and perfect virtue that men attain." ${ }^{74}$ Although the proposed female model of humanism theoretically challenged male scholars to rectify women's intellectual achievements with their perceived feminine inferiority, Quirini - in the tradition of Boccaccio - rationalized his praise of Nogarola's accomplishments by likening her to a man and male virtues. Quirini exalted Nogarola's dedication to philosophy through the monastic life, providing that she was among the most exemplary members of her sex because she had emulated great men by embracing chastity as a model for scholarship. ${ }^{75}$ Her decision to withdraw from the world to preserve her virtue also complied with traditional social prescriptions of femininity; her transition to writing

\footnotetext{
${ }^{73}$ King and Robin, Complete Writings, 2.

${ }^{74}$ King, "Book-Lined Cells," 76.

${ }^{75}$ King, "The Religious Retreat of Isotta Nogarola," 813.
} 
about religious rather than secular topics was also heralded as more feminine and natural, even for a woman who had perceivably overcome the frailty of her sex. Now viewed as an asexual holy figure rather than a woman, Ludovico professed, "In my memory, I survey your little cell, which from every corner breathes forth sanctity. I think of the sacred relics ... I put before my eyes those pictures portraying the saints, the robes embroidered with designs of crosses and the images of the blessed ... which brought me a kind of foretaste of paradise." 76 Likewise, Veronese scholar Paolo Maffei wrote, "But for you the virginity of Mary, who brought God to earth, is put forward as an exemplar of perfect holiness ... And so let Mary be for you, O Isotta, the unique model of living, of morality, of the worship of God, of the cultivation of virtue, so that ... you must try as much as it be possible to imitate and to enact her image in your mind and body." ${ }^{\prime 77}$ As a woman, she could engage in humanist dialogues without reproach as long as she chose appropriate topics for discussion, confined herself to a monastic existence, and divorced herself from her gender; she had to emulate Mary's virginal, passive qualities. The metamorphosis in her identity from a secular academic to a holy woman was esteemed by the men of patriarchal Renaissance society.

Similarly, female humanist Constanza Varano heralded Nogarola's erudition and chastity, for in her estimation, Nogarola had embraced a holy life wholly devoted to her studies; Varano told Nogarola that, "nothing can be more profitable and more fruitful for women than to put aside the comforts of the body and to strive zealously for those things which fortune cannot destroy." 78 Nogarola's "manliness of mind" was praised by many

\footnotetext{
${ }^{76}$ Abel, II, 123:16-124:7, translated in King, "Thwarted Ambitions," 286.

${ }^{77}$ Abel, II, 25-6, translated in Jardine, "Isotta Nogarola," 288.

${ }^{78}$ Ibid.
} 
even though she now professed that, "divine order of things, decreed at the time of creation" made her unworthy of their esteem. ${ }^{79}$ Although as a younger woman she claimed that she was exceptional and felt "no shame in being a woman," after emerging from decades of solitude, she admitted to Foscarini that, "My sex, too, and my current way of life also urge me to be silent ... I have dared to send you this letter not, as I said from the first, so that I might demonstrate to you, a most learned and eloquent man, the strength of my intellect or my ability to write, of which I have none." ${ }^{80}$ Unlike male humanists who spoke about the modesty of their work solely for the sake of demonstrating proper humility, Nogarola stated that her inadequate contributions stemmed from her ineptitude, nature, and sex. ${ }^{81}$ Once ambitious and bursting with enthusiasm, Nogarola now appeared lifeless; rejected by humanists, defeated by society, and bound to a life of solitude, she embraced the fate of her decision to remain married only to learning. While she corresponded with a number of humanist scholars and politicians in the last decade of her life, she was extremely self-deprecating in her replies. Nogarola remained in virtual solitude for twenty-five years before dying alone in her libraria cella, her "book-lined cell." 82

In the century following Nogarola's death, the attacks against her character which tarnished her reputation and ultimately led to her self-imposed seclusion had been effectively forgotten. In 1545, Italian scholar Giuseppe Betussi translated Boccaccio's biography of famous women, De mulieribus claris (1362), into Italian and added

\footnotetext{
${ }^{79}$ Lisa Jardine, “'O Decus Italiae Virgo', or the Myth of the Learned Lady in the Renaissance," The Historical Journal, 28, no. 4 (1985): 808; King, "Book-Lined Cells," 73.

${ }^{80}$ Isotta Nogarola, Complete Writings: Letterbook, Dialogue of Adam and Eve, Orations, ed. and trans. by Margaret L. King and Diana Maury Robin (Chicago: University of Chicago Press, 2004), 129-31.

${ }^{81}$ King, "The Religious Retreat of Isotta Nogarola," 811.

${ }^{82}$ Nogarola, Complete Writings, 102.
} 
illustrious Italian women to the work. Nogarola was included in the collection and praised as, "most learned and most wise" in what became one of the most widely-read biographical collections of the sixteenth century. ${ }^{83}$ In the tradition of Boccaccio, Betussi’s biography first highlighted Nogarola's virginity as virtuous and then sanctifies her for remaining unmarried. Rewriting history by suggesting that chastity alone determined her course rather than academic ambition, Betussi states, "However much her father urged her to take a husband ... so firmly was chastity rooted in her heart that there was no shaking her from that praiseworthy resolution of hers." ${ }^{84}$ It was both her focus on religious subject matter in her later life and her cloistered existence which increased prominent men's esteem of Nogarola. In Betussi's account, having "seen her and heard her, [Cardinal Greco's] admiration rather grew stronger than otherwise, such that he judged her to be not mortal, but divine." ${ }^{\prime 85}$ Nogarola embodied the Renaissance ideal of virginal purity and Christian devotion, which overshadowed her individual academic aptitude. While Betussi does acknowledge that Nogarola, "showed herself the equal of the most scholarly men of that age" and that, "she gave herself completely to the study of letters, in which she was made such great profit that one could truly say that the ancient Latin language had returned in full forced; indeed, with no small dignity, she bettered it," 86 he also clearly emphasizes that Nogarola complied with social convention. Nogarola was not primarily heralded in his collection because she was a capable woman,

\footnotetext{
${ }^{83}$ Giuseppe Betussi, Libra di M. Gio. Boccaccio delle donne illustri, tradotto per Giuseppe Betussi (Venice: Pietro de Nicolini de Sabbio, 1547), 151a-b, translated in Ross, The Birth of Feminism, 98; Nogarola, Complete Writings, 96.

${ }^{84}$ Betussi, 154b, translated in Ross, The Birth of Feminism, 98.

${ }^{85}$ Ibid., $155 \mathrm{a}-\mathrm{b}$.

86 Ibid.
} 
but because she was a product of Italy's virtuous society and the civically restorative humanist endeavor.

As Isotta Nogarola's experience demonstrates, learned women were expected to abandon a life of study in favor of marriage and docility. Social prescriptions mandated that mature women assume their proper place in the patriarchal order, which was either wife or nun. Chastity was women's one great virtue, and a single woman lobbying for acceptance into male society, Nogarola unchastely abandoned sexual propriety. Unmarried, learned women were perceived as sexually distorted members of a third sex who aroused fear and hostile retaliation from both men and women in quattrocento Italy ${ }^{87}$ As such a woman, Nogarola was ultimately presented with a choice: marriage and social acceptance or study and social isolation. In order to continue her engagement with humanism, Nogarola had to adhere to patriarchal ideology. Although her decision to retreat from society seemed self-imposed and was in some ways morally and socially redemptive, it was, in reality, communally mandated and painfully repressive.

${ }^{87}$ King, "Book-Lined Cells," 79. 


\section{DEFENSE OF THE LIBERAL INSTRUCTION OF WOMEN: THE PUBLIC LIFE OF LAURA CERETA}

In the patriarchal system of early Renaissance Italy, educated women were deemed an anomaly, and as such, were often seen as suspect by both fellow scholars and, in particular, members of their own sex. Their visibility within society was interpreted as the abandonment of female sensibilities and a challenge to the binary gender system which expected women to be socially invisible. ${ }^{88}$ Although some male humanists praised educated women for their masculine sensibilities, female scholars like Brescian Laura Cereta (1469-1499) were often confronted with accusations of plagiarism, unchastity, and arrogance. While it is important not to generalize and assume that all educated women were perceived as threats to traditional social conventions, many learned adult women were treated as dangerous and subversive; social order, patriarchy, and the patrilineal, patrimonial system all depended upon female passivity and compliance, which vocal humanist, Laura Cereta, openly challenged.

Born into the Brescian aristocracy, Laura Cereta was given the advantage of education as a result of both her lineage and her father Silvestro's tutelage. After receiving a primary education at a convent during her childhood, Cereta's humanist instruction in classical languages and disciplines was directed by her father. As Cereta

${ }^{88}$ Cox, Women's Writings in Italy, 20. 
wrote, her father was "the active governor of the family," 89 and notably, the financial and emotional benefactor of her intellectual pursuits. Under Silvestro's guidance, Cereta became exceptionally well-versed in humanist disciplines, concentrating on Latin eloquence, discourse, and Petrarch's model of academic writing. ${ }^{90}$ Her marriage to Venetian merchant Pietro Serina at fifteen did not force Cereta to discontinue her studies, as some historians have suggested was an inevitable fate for educated girls. As her letters imply, her husband's frequent absence allowed her to maintain a productive scholarly life at night, which was a privilege not often afforded to young married women. ${ }^{91}$ The eighteen months between Cereta's marriage and her husband's untimely death were her most productive: she wrote letters on behalf of both her husband and father, initiated literary correspondences with fellow humanists, and started composing a collection of Latin letters and orations. ${ }^{92}$ As Sarah Ross notes, "Cereta served as a worthy heir to her intellectual family,"93 and her father's continued guidance gave Cereta both the social and economic capital to pursue humanist study even after marriage. While she was still within the appropriate confines of patriarchal authority, Cereta's confidence and talents were put on full civic display.

\section{A Seeker of Fame and Immortality}

Modesty was not, by all accounts, one of Laura Cereta's finer virtues. At the height of her academic career, Cereta wrote to local scholars and fellow humanists with the expressed desire to display her knowledge and find a patron outside of her father who

\footnotetext{
${ }^{89}$ Ross, The Birth of Feminism, 50.

${ }^{90}$ King and Rabil, Her Immaculate Hand, 23.

${ }^{91}$ Amyrose McCue Gill, "Fraught Relations in the Letters of Laura Cereta: Marriage, Friendship, and Humanist Epistolarity.” Renaissance Quarterly 62, no. 4 (Winter 2009): 1107.

92 Ibid., 1101.

${ }^{93}$ Ross, The Birth of Feminism, 110
} 
championed her works and publicized her brilliance. ${ }^{94}$ As Renaissance scholars have noted, Cereta believed herself to be remarkable, actively pursued academic fame, and disregarded the feminine conventions of humility generally adhered to by her humanist predecessors, all in a quest for intellectual immortality. ${ }^{95}$ Perceiving herself as an heir to an illustrious legacy of impressive women from history, Cereta proclaimed that she was, "driven to demonstrate how much virtue and literary fame has been left behind by that eminent female lineage which [she] bears in [her] heart and which intelligence (generous patroness that she is) has always and ever glorified." ${ }^{" 96}$ Even further, she asserted that, "hereditary possession is indisputable and legitimate, which has descended eternally from one age to the next and all the way to me. ${ }^{, 97}$ Cereta, herself, made reference to her ambition as an inheritor of "the intellectual and cultural legacy of generations of learned women" in a letter to her cousin Bernadina di Leno, stating, "After the fruits of my study ripened and the golden grain fell from the stalk, I began to gather the harvest with my rustic pen, so that it could safely and quickly be transported to faraway peoples of the world ... And, with you as my judge, this work can win a place for me, a woman writer, among the most highly praised of our ancestors. ${ }^{998}$ After the death of her husband, Cereta compiled and published eighty-two of what she deemed her most impressive works and, with the support of her father, published them as a collection..$^{99}$ The overarching argument of her letters is that patriarchal society fosters ignorance and not intelligence by glorifying ridiculous women.

\footnotetext{
94 Ibid., 50.

${ }^{95}$ King, "Book-Lined Cells," 71; Gill, "Fraught Relations," 1102.

${ }^{96}$ Laura Cereta, Laura Cereta Brixiensis, 188-9, as cited in Ross, The Birth of Feminism, 154.

${ }^{97}$ Laura Cereta, Collected Letters of a Renaissance Feminist, ed. and trans. by Diana Robin. (Chicago: University of Chicago Press, 1997), 76n40.

98 Ibid., 76n40, 51-2.

${ }^{99}$ Ruggiero, The Renaissance in Italy: a Social and Cultural History of the Rinascimento, 376.
} 
Many of Cereta's letters focus on the notion that both men and women embrace frivolity over substance. She argues that all people, regardless of their gender, have a propensity for learning and that, "Nature bestows one license upon everyone and in equal measure: that of acquiring knowledge. ${ }^{" 100}$ Supporting oppressive patriarchal ideology and remaining willfully ignorant is, in her estimation, a choice, for, "Choice makes all the difference, since choice along determines conduct." Her writing clearly argued that women choose ignorance and passivity, and men choose jealousy and vengeance. These poor choices, in Cereta's assessment, are what led men to lobby jealous charges against her, to which she promised to, "fight to annihilate the reprehensible slander of these noisy morons with [her] weapons of vengeance." ${ }^{101}$ As a self-perceived champion of esteemable women, she further asserted that, "some disreputable cretins and madmen, egged on by this kind of nonsense, make rabid assaults upon the Republic of Women, which instead deserves reverence." ${ }^{102}$ The aggressive masculine language she appropriated and her commitment to retribution against such men undoubtedly won Cereta few male allies.

Cereta's discourses on gender ideology and the education of women were unique for her time because she not only indicted men, but women as well. In a series of letters written to both historical and fictional characters, Cereta lobbied for the education of women, but did so by condemning misogynistic practice and the frivolity of her own sex. She criticized women's acceptance of the unnatural foundation of marriage, which as she argued, bounds them to men like animals and relegates them to a lifetime of tedious work

\footnotetext{
${ }^{100}$ Laura Cereta, Laura Cereta Brixiensis, 188-9.

${ }^{101}$ Ibid., 194-5.

102 Ibid.
} 
and isolation. ${ }^{103}$ Cereta also contended that women were held to an oppressive, sexual double standard and that, "the advantages of matrimony are all on the male side ... women debase themselves like animals in marriage and the end they meet is widowhood, poverty, and grief."104 Women's way out of oppression, she reasoned, was education, but it was not only patriarchal social constraints such as marriage which kept women in chains, but women themselves.

The criticism Cereta directed towards women in her letter to the fictitious Lucilia Vernacula were not subtle and, like the equally brutal attacks she waged against men, greatly influenced the social reception she received from her contemporaries. It was Cereta's contention that virtue and learning were the products of hard work and that empty women valued pleasure over knowledge. "O the weakness of our sex, topping to voluptuousness," ${ }^{105}$ she mocked, further stating that lazy and dull-witted women have, "given up hope of attaining knowledge of the humane arts, when they could easily acquire such knowledge with skill and virtue." ${ }^{106}$ Cereta continued by stating:

Besides, these women, being idle with time on their hands and no interests of their own, occupy themselves with keeping watch over other people's business, and, like scarecrows hung up in the garden to get rid of sparrows, they shoot poison from the bows of their tongues at those who cross their paths ... Mildew in the mind afflicts [those, who] ... can't stand to hear even the epithet 'learned women.' 107

As Cereta points out in her letter to Bibolo Semproni on the defense of women's education, her own intelligence is proof that nature gives both men and women the ability

\footnotetext{
103 Gill, "Fraught Relations," 1106-8.

${ }^{104}$ As summarized by Diana Robin and cited in Ross, The Birth of Feminism, 152.

${ }^{105}$ Laura Cereta, Letter to Augustinus Aemilius, Curse against the Ornamentation of Women, as cited by King and Rabil, Her Immaculate Hand, 79.

106 Cereta, Collected Letters, 82.

${ }^{107}$ Laura Cereta, Letter to Lucilia Vernacula, as cited by King, Renaissance Humanism, 281.
} 
to use reason; ignorance is a socially-accepted mask men mold and women wear. As a self-appointed successor of women intellectuals, Cereta believed herself qualified to criticize both the ignorance of female society and the misogyny of male ideology. It was, perhaps, her aggressive pursuit of acknowledgement within the humanist community, coupled with the content of her letters, which caused both male and female scholars to ignore her explicit appeals for acceptance. Cereta, it seems, wrote only to enemies and had few allies; she is the only notable female humanist of her time that did not regularly correspond with either prominent male or female academics. ${ }^{108}$

\section{From Defiance to Defeat}

Although she was a woman of impressive intellect, Cereta's use of defiant, abrasive language and her unapologetic arrogance were seen as subversive and alienated her from both the social and academic worlds. By Renaissance standards, her sensibilities were very masculine: she chose to write about social ills and gender disparity rather than more feminine, acceptable religious topics; she published her work under her own name with the intent of gaining glory; she had an unusual degree of social visibility for a woman; and she sought vengeance against enemies. As such, accusations of plagiarism were lobbied by fellow scholars, and women criticized her unchaste and assertive manner. In a letter to Cereta's father, Dominican Tommaso of Milan wrote, "she gives herself to things unworthy of her," and advised that she should retreat into religious study and, "Blunt [her] pen and time it with the file of modesty." 109 Instead of heeding his advice and retreating into isolation, Cereta fought back: she wrote an invective against male critics who, "vomit forth muddy opinions from the bilgewater of envy"; she

\footnotetext{
108 Jardine, "O Decus Italiae Virgo," 801.

${ }^{109}$ King, Women of the Renaissance, 202.
} 
petitioned for public exoneration and justified her actions by claiming that her work, "stirred up the envy of a number of men, who cruelly sharpened the tenth of their spite against me"; and she penned counterattacks against male and female critics alike to make clear the fact that she was, "not a woman who wants the shameful deeds of insolent people to slip through under the pardon of silence." ${ }^{110}$ In a society which valued female compliance and invisibility, Cereta was anything but feminine.

Cereta seemingly modeled herself on male humanists and appropriated masculine courtroom and vendetta language in her correspondences for academic purposes. ${ }^{111}$ In the tradition of Boccaccio, she also promoted male virtues as normative and embraced the patriarchal ideology which faulted women for their weak character. While she may have hoped that by appropriating male humanists' rhetorical and philosophical style she would increase her esteem among the intellectual community, her aggressive nature was by all accounts repellant to both men and women. Her ability to participate in the humanist dialogue in any manner was likely the product of her father's benefaction and influence, for she did not comply with patriarchal ideology or social prescriptions of femininity. Even under the advisement of the academics she lobbied to win the approval of, Cereta did not censure herself.

Cereta's assertiveness in her early career was not only seen as an affront to men and women in her community, but to her female academic contemporaries. She wrote a scathing criticism of humanist Cassandra Fedele after her correspondence went unanswered, stating that, "Cassandra attacks me ... possibly motivated by the string of envy, she takes pain to poke holes in my knowledge ... she believes that the things I have

\footnotetext{
${ }^{110}$ Rabil, Laura Cereta, 13; Laura Cereta, Collected Letters, 39; King, Renaissance Humanism, 274.

${ }^{111}$ Ross, The Birth of Feminism, 154.
} 
written are not mine but came from the pen of the father who educated me ... For it is by no means easy for the hot and burning throat of envy to quench its greedy thirst for verbal abuse." ${ }^{112}$ Cereta's published letters provide historians with detailed accounts of her feuds and clearly illustrate her intelligence, which in places reads as arrogance, as justification for her retribution. "What after all is the purpose of honor if I were to believe that the barking roars of these sharp-tongued women were worth tolerating ... even dogs are allowed to protect themselves from more aggressive fleas by crushing them with their nails, ${ }^{, 113}$ she reasons. The aristocratic position of Cereta's family within her community provided her with a high-profile platform for her indignant replies to her many detractors. Again, the license she took undoubtedly stemmed from her privilege.

While her social and academic reception may have been markedly negative during her father's life, she was still granted the academic and public freedom that came with his role in the social order. Upon his death six months after the publication of her letters, however, Cereta became notably silent. As Sarah Ross argues, “[Silvestro's] death coincided with Cereta's decision to abandon humanistic endeavor in favor of a quasicloistered existence." ${ }^{114}$ Without a paternal figure - either father, husband, or patron - to legitimize and support her academic career, Cereta's opportunities were limited. As Isotta Nogarola's fate made evident, a single woman not under the guidance or protection of a patriarch rarely had a legitimate, socially-appropriate position within the academic world. Unlike Nogarola, however, Cereta refused to comply with social ideology to maintain her humanist career: she did not transition into writing about religious matters, did not get

${ }^{112}$ Cereta, Collected Letters, 146-7.

${ }^{113}$ Ibid., 82.

${ }^{114}$ Ross, The Birth of Feminism, 51. 
remarried to secure patriarchal support, and did not reemerge from her isolation with a tempered, asexual persona.

Once a prolific writer, Cereta quickly faded into obscurity and published nothing for the remaining eleven years of her life. ${ }^{115}$ Cereta may have been gifted with a keen and inquisitive mind, but she was also burdened by her defiant temperament; educated women were tolerated only when they adhered to traditional notions of femininity that instructed them to be both silent and humble. Unfortunately for Cereta, she was neither. It was not simply, as Ross suggested, her father's death alone which led to Cereta's reclusiveness and abandonment of humanism, but the fact that she had alienated herself from society. Had she successfully secured the patronage of another patriarchal figure, as she attempted to do earlier in her career, it is reasonable to assume that she would not have been forced into silence by her father's death. As Isotta Nogarola's situation demonstrates, it was not her status as a woman that ended her career when her father died, but her refusal to adhere to prescriptions of femininity. Now "absent from [her] father in time and place," ${ }^{116}$ Cereta was forced to withdraw from humanism because she lacked a legitimate patriarchal sponsor. As a widow without a father or patron, she could not operate within the patriarchal system or humanism without inviting harsh criticism. Her desire for fame and immortality were undoubtedly left unquenched after his death, but it was her resistance to social convention during his life that sealed her academic fate. Unfortunately, once outside of her father's auspices, Laura Cereta no longer had the social capital or financial support to either openly participate in the academic culture of

\footnotetext{
115 King, "Her Immaculate Hand," 24.

116 Rabil, Laura Cereta, 13.
} 
fifteenth-century Renaissance Italy or publish her works with any form of patriarchal endorsement, and her humanist career abruptly came to an end. 


\section{THE WORTH OF WOMEN: THE PRIVILEGED LIFE OF MODERATA FONTE}

Chastity was directly linked to a woman's unassuming presentation and silence.

Women such as Laura Cereta encountered hostility from female contemporaries because they vocalized their opinions and had an uncharacteristic level of social visibility. ${ }^{117}$ Speech was seen as seductive, immoral, and unchaste, and women's participation in the traditionally-male social realm threated the patriarchal order. ${ }^{118}$ Letter writing and engaging in written dialogues were, therefore, more appropriate means of female communication when social conventions were followed because they were solitary and preserved virtue. While engaging in public oration was viewed as indecorous for adult women, dialogue writing was socially proper. ${ }^{119}$ It is for this reason that the written discourse was the most frequent genre of writing female humanists such as Moderata Fonte used to engage in moral reflection, theological contemplation, and academic debate. ${ }^{120}$ Through her written dialogues, Fonte was able to successfully participate in humanist circles and speak to feminist concerns without being construed as either subversive or immoral.

\footnotetext{
${ }^{117}$ Cox, Women's Writings in Italy, 7.

118 Panizza, Paternal Tyranny, xxvi.

${ }^{119}$ Cox, Women's Writings in Italy, xix.

${ }^{120}$ Mitchell and Mitchell, Taking Sides: Clashing Views on Controversial Issues in Western Civilization, 123.
} 
The daughter of a lawyer in the Venetian citizens' class, Moderata Fonte (15551592) was not born into wealth or aristocratic privilege. Raised by grandparents after her parents' death, she was tutored in literature and poetry by her grandfather, who recognized her quick intelligence and desire for knowledge. ${ }^{121}$ Venice, a city with a thriving humanist community and prominent intellectual salons by the mid-sixteenth century, supported Fonte's educational ambitions, especially after family friend Giovanni Niccolò Doglioni became a herald and patron of her work. Doglioni, who later wrote Fonte's biography after her death, said of his intellectual protégé that her steadfast character, her extraordinary talent in everything she tried, and her devotion to learning impressed upon him "her remarkable and unique gifts;" Fonte, he believed, had such an exceptional talent that he resolved "to reveal it to the world." 122 Doglioni's patronage not only greatly influenced the course of Fonte's career, but her public reception as well.

\section{The Making of a Feminist Housewife}

Moderata Fonte, also known by the nom de plume Modesta Pozzo, was not a radical insurgent who publicly challenged the patriarchal order of her native Venice or openly resisted feminine social constructions. As an unmarried girl navigating the social and academic spheres of Venice, Fonte actually adopted her nom de plume to protect both her modesty and her family's reputation. ${ }^{123}$ Perceivably influenced by the criticism lodged against earlier female humanists, Fonte's use of a pseudonym also allowed her publicly assume the role of married woman rather than tying her identity to her family of

\footnotetext{
${ }^{121}$ Janet Smarr, Joining the Conversation: Dialogues by Renaissance Women. (Ann Arbor: University of Michigan Press, 2005), 5.

${ }^{122}$ Moderata Fonte, The Worth of Women, ed. and trans. by Virginia Cox. (Chicago: University of Chicago Press, 1997), 35-6.

${ }^{123}$ Virginia Cox, "Introduction," in The Worth of Women, by Moderata Fonte. (Chicago: University of Chicago Press, 1997), 5.
} 
origin. Unlike Laura Cereta, whose career was intrinsically bound to her father, and who overtly sought fame and immortality through her work, Fonte wanted only to improve the conditions of women's lives and worked in relatively obscurity as a young scholar. A Venetian woman, living within the confines of a highly patriarchal society, Fonte did not openly engage with men in public and had limited, structured interactions with other humanist scholars, presumably under the direct supervision of Doglioni. Scholar Francesco Sansovino, a contemporary of Fonte's, set her apart from earlier female humanists such as Cereta who sought to gain fame and other accolades traditionally defined as masculine by saying that she was, "extremely learned in all disciplines, as far as one can gather (for to tell the truth, no one can actually claim to have seen her in person)." ${ }^{124}$ By writing religious poetry, which was considered appropriate for young, unmarried women, ${ }^{125}$ and dialogues, which showcased her voice in an indirect manner, Fonte was strategically able to pursue a life of scholarship while still preserving her chastity and reputation.

In the years before her marriage, Fonte was a prolific writer and poet, who, with the support of Doglioni, made a name for herself within Venetian humanist circles. Praised by her patron as an "erudite maiden," whose allegiance to the professional class and use of the Venetian dialect allowed her works to circulate "in the hands of the most excellent literati," Fonte maintained strong ties to her intellectual family and personified the "elite" education and diversity of talent sought after by Renaissance scholars. ${ }^{126}$ Known as a cittadina - an active participant in the Republic and charitable patron - Fonte

\footnotetext{
${ }^{124}$ Smarr, Joining the Conversation, 193.

125 Ross, The Birth of Feminism, 209.

${ }^{126}$ Malpezzi Price, Moderata Fonte. (Danvers: Rosemont Publishing and Printing Corp., 2003), 10; Ross, The Birth of Feminism, 199-202.
} 
had the economic and social privileges that came with both her class and her affiliation with her patron, who himself was considered a respectable humanist. ${ }^{127}$ It was Doglioni who both introduced her works to the public by promoting and financing her publications and arranged her marriage. ${ }^{128}$ With his support, and operating safely within the confines of patriarchal society, Fonte produced acclaimed poetry and prose, effectively establishing a new paradigm of Venetian humanist/wife/mother. ${ }^{129}$ In her book, Moderata Fonte, historian Malpezzi Price notes that, "From within the accepted social structures of the patriarchal family and society and from within the recognized literary genres of the epic and the dialogue, Fonte was able to elaborate and divulge a non-conformist message which helped gradually to modify certain aspects of the prevalent social ideology with regard to women." ${ }^{\prime 30}$ By adhering to traditional prescriptions of femininity and working under the tutelage of an esteemed patriarch and humanist, Fonte continued her academic career with the support of her society. As Fonte's success proves, past historiography which has suggested that sixteenth-century learned Venetian women were either social outcasts or perceived as asexual anomalies is flawed; she was a well-respected member of Venetian society who strategically balanced the roles of scholar, wife, and mother. Although marriage and motherhood may have limited Fonte's time for study, her dedication to intellectual pursuits did not waiver after she reached the age of sexual maturity and left her family of origin. Married at the late age of twenty-seven to a younger man with his own notable intellectual talent, and who supported and praised his

\footnotetext{
${ }^{127}$ Malpezzi Price, "Venetia Figurata and Women in Sixteenth-Century Venice: Moderata Fonte's Writings," in Italian Women and the City: Essays, ed. by Janet Smarr and Daria Valentini, 18-33. (Madison: Fairleigh Dickinson University Press, 2003), 25.

${ }^{128}$ Smarr, Joining the Conversation, 5.

${ }^{129}$ Ross, The Birth of Feminism, 204.

${ }^{130}$ Price, Moderata Fonte, 20-1.
} 
wife's excellence, Fonte nurtured her scholarly pursuits in the evenings. Although her biographer Doglioni stated that Fonte excelled in both her role as wife and mother, her works hint at the frustration she felt at having little time to devote herself to literary endeavors; ${ }^{131}$ by conforming to her culture's prescriptions of what were considered proper female roles, Fonte's independence was limited. The work that she did produce during this time, however, was her most acclaimed, in part because it addressed the reality and restrictions of women's social positions. Il merito delle donne, or The Worth of Women, was written in the tradition of a querelle des femmes and speaks to women's desire for social, political, intellectual, and institutional equality. ${ }^{132}$ Fonte aptly constructed her feminist treatise as a fictional dialogue of women, and in it, challenged misogynistic views about female friendship, education, and marriage without blatantly attacking the social order or bringing criticism upon herself or her family.

Operating within a rhetorically-appropriate genre of writing for women in the late sixteenth century, Fonte's fictional dialogue is a multi-voiced conversation between women of varying perspectives, ages, and social stations. As Janet Smarr notes in her book, Joining the Conversation: Dialogues by Renaissance Women, dialogues "blur the distinction between private and public, indoors and outdoors, private female society and society more generally ... [which] helped later women such as Fonte address the public while claiming to be speaking only to an intimate circle of female friends." ${ }^{" 133} \mathrm{By}$ structuring her work in the hypothetical, and by employing multiple voices, Fonte was at liberty to discuss socially improper or controversial topics without explicitly aligning

\footnotetext{
${ }^{131}$ Ibid., 35.

${ }^{132}$ Ross, The Birth of Feminism, 277.

${ }^{133}$ Smarr, Joining the Conversation, 193.
} 
herself with any of her characters' positions; thereby, she avoided allegations of impropriety. As Fonte writes:

There was once not long ago (and indeed there still is) a group of noble and spirited women, all from the best-known and most respected families of the city, who, despite their great differences in age and marital status, were so united by breeding and taste that a tender bond of friendship had formed between them. These women would often steal time together for a quiet conversation; and on these occasions, safe from any fear of being spied on by men or constrained by their presence, they would speak freely on whatever subject they pleased. ${ }^{134}$

Although Fonte uses her characters' voices to challenge the institution of marriage and the constraints of patriarchal society, her delivery is subtle and cleverly expresses feminist concerns in an honest, yet passive, manner. ${ }^{135}$ As is clear in Fonte's dialogue, some of the characters were constructed in her likeness, but her overall message still remained inclusive of all women's experiences. The collective group eloquently expressed the ambivalence, limitations, and concerns of female life - including marriage, motherhood, and lack of education - while still working within their social structure and respecting the virtues of the Republic.

Fonte strategically walked the line between overtly challenging the existing social order and complying with patriarchal ideology regarding women's social visibility and limited civic participation. In The Worth of Women, not all of Fonte's characters advocate for socially acceptable positions; her main character, Corinna, is determined to remain single. Another member of her noble female group, Lucrezia, makes the following statement to Corinna:

God has endowed you with such a soaring intelligence that you delight in the pursuit of excellence, and devote your every lofty thought to the study of letters, human and divine, so that one might say you have already embarked on a celestial life while still surrounded by the trials and dangers of this world. Though such

\footnotetext{
${ }^{134}$ Fonte, The Worth of Women, 44-5.

${ }^{135}$ Ross, The Birth of Feminism, 278.
} 
trials barely touch you, for, by rejecting all contact with the falsest of creatures, men, you have escaped the tribulations of this world and are free to devote yourself to those glorious pursuits that will win you immortality. But perhaps you should ... write[] a volume on the subject, as an affectionate warning to all those poor simple girls who don't know the difference between good and evil, to show them where their true interests lie. ${ }^{136}$

A conversation between the women ensues regarding why men are women's superiors when they are imperfect and Corinna responds that, "This pre-eminence is something they have unjustly arrogated to themselves ... [they] set themselves up as tyrants over us, arrogantly usurping that domination over women that they claim is their right, but which is more properly ours." ${ }^{\prime 137}$ As Fonte infers through her characters' continuing discussion, women are legally subordinated to men and have little civic autonomy. As the women's witty conversation illustrates, intellectual autonomy, on the other hand, is a matter of personal prerogative and can be fostered through education. Men fear female potential and, as such, keep women socially and economically oppressed because they want to retain their monopoly on positions of power. ${ }^{138}$

Fonte's prerogative in The Worth of Women was not simply a reiteration of the contemporary humanist dialogue of the time, thus, it effectively contests Margaret King's theory that, "In all the works of the humanists of whatever genre there was much that was imitative, conventional, repetitive ... they also had an inflated sense of the importance of what they wrote ... they were conferring immortality both on the person addressed and on themselves." ${ }^{139}$ Fonte's opinion was anything but conventional, and the fact that her work was published posthumously under a nom de plume challenges the notion that she

\footnotetext{
${ }^{136}$ Fonte, The Worth of Women, 48-9.

${ }^{137}$ Ibid., 59.

138 Price, "Venetia Figurata," 26.

${ }^{139}$ King, Her Immaculate Hand, 26.
} 
wrote for personal glory. What The Worth of Women represents is a feminist courtier;

Fonte used her all-female cast of characters to speak openly to modern issues. ${ }^{140}$ Again, Fonte strategically walked the line by addressing the public from a distance and criticizing society indirectly through her characters' voices; her narrative voice is audible, but Fonte is still appropriately socially invisible.

\section{Praise for a Virtuous Citizen}

Although Fonte was forced to limit her academic pursuits after marriage, her esteem as a female humanist increased because of her role as wife and mother; she was praised by male scholars for her social compliance, traditional lifestyle, and feminine virtue. ${ }^{141}$ Malpezzi Price notes that, "Her success, her writings, and her message are remarkable, as she was able to write and thrive within the patriarchal confines of Venetian society ... public authorities recognized that, thanks to her poetic skill, she 'adorned' their city." 142 By the turn of the seventeenth century, the intellectual milieu of Venice supported female humanists like Fonte, in part, because their achievements were seen as virtuous; the notion that intelligent, classically-educated citizens served the needs of the state through their edification was a founding tenant of humanism that had been more widely embraced and expanded to women who could prove they were virtuous. Fonte exemplified the civic value of humanism, the glory of the Republic, and the virtue of motherhood by providing for the education of her children and increasing the prestige of her city. More than a century had passed since Isotta Nogarola first endeavored to live as a female humanist in Venice, and since that time, both humanism and the notion of

\footnotetext{
${ }^{140}$ Ross, The Birth of Feminism, 284.

${ }^{141}$ Hurlburt, “A Renaissance for Renaissance Women?” 195.

142 Price, Moderata Fonte, 20.
} 
female education had become more firmly rooted in Italian society. While The Worth of Women was published posthumously in 1600 by her patron, Doglioni, after her untimely death, Fonte's name appeared in the On the Notable Features of the City of Venice guidebook as early as 1580 , which confirmed that she was praised during her lifetime as a "young maiden, an honored citizen of this city, being very knowledgeable, especially in Poetry $[$ sic $] .{ }^{\prime 143}$ Fonte's literary works and chastity thus contributed to the virtue, esteem, and favor of her city. Her positive reception during her lifetime not only reflected the quality of her work, but the traditional role she held in Venetian society as a wife and mother willing to assume a passive, confined life within her home molding future Venetian citizens and glorifying the Republic with her writing.

Although Fonte was not specifically mentioned in the letters of contemporary women outside of humanism and literary scholarship, it is reasonable to assume that the publication of The Worth of Women after her death only served to increase her esteem among both male intellectuals and Venetian women. Women-led salons were a feature of Venetian society in the seventeenth century, and Fonte's work in many ways legitimized their existence and advocated for their purpose. As Sarah Ross points out, "The posthumous publication of Fonte's Il merito delle donne (1600) offers a carefully crafted image of the author as a proper family woman ... the quantitative aspect of Il merito's history, however, pales in comparison to its qualitative reception. Male encomiasts cited all of her publications but gave Il merito pride of place."144 One of many renowned male scholars who praised both Fonte's publication and virtue, Peitro Paolo di Ribera, commented that the brilliance of her sex and work are a "refutation of some men who had

\footnotetext{
${ }^{143}$ Cox, The Worth of Women, 21; Price, Moderata Fonte, 9.

${ }^{144}$ Ross, The Birth of Feminism, 209, 285.
} 
failed to give women credit for wisdom, judgment, knowledge, and courage ... Indeed, on the judgement of knowledgeable people, it compares favorably with anything published these days." ${ }^{145}$ Her patron's biography, perhaps, best explains why Fonte was so well received within both social and academic circle. Doglioni reflects:

Madonna Modesta brought [her children] up with all possible diligence, perfecting the most refined of skills in them; and certainly, few children of their age can be compared with them ... [she] was extremely good at running her household: so good, indeed, that her husband scarcely needed to give it a thought and confessed on several occasions that ... she took everything out of his hands and did it all herself, with extraordinary efficiency and diligence. ${ }^{146}$

Fonte was the epitome of feminine virtue: she was a mother devoted to raising extraordinary Venetian citizens; she was a decorous and subservient wife, who selflessly and silently attended to the needs of her husband; and, above all, she conformed to the patriarchal order. The success and longevity of her humanist career were a direct result of her adherence to traditional prescriptions of femininity and her economic, public patriarchal support. Unlike Isotta Nogarola, who resisted marriage and was outcast by society, and Laura Cereta, who had a defiant temperament and was alienated by society, Moderata Fonte successfully challenged the social order from within the confines of her traditional life, and was, therefore, embraced by society.

\footnotetext{
${ }^{145}$ Ibid., 285.

${ }^{146}$ Fonte, The Worth of Women, 37-8.
} 


\section{PATERNAL TYRANNY: THE CLOISTERED LIFE OF ARCANGELA}

\section{TARABOTTI}

By the seventeenth century, Renaissance Italy had more fully embraced the humanist discipline, which included the education of some elite women. While the extension of a humanist education provided women with increased visibility and prominence within academic circles, in Northern Italian republics such as Venice, their social visibility was still largely determined by their gender. Women in the seventeenthcentury patriarchal system remained under the care of fathers or male guardians and were often left with little choice in the direction of their lives, even if they were raised within intellectual families. Even though learned women were no longer socially anomalous figures at this time, they were still generally only offered the same two appropriate life choices presented to their medieval progenitors: marriage or the convent. Although some humanist women freely "chose the convent as intellectual and marital sanctuary,",147 others, like Arcangela Tarabotti, were given no choice in the matter and were cloistered against their will. While Sarah Ross contends that by the seventeenth century, "The father or father-patron become less crucial as a means to securing legitimacy" and that humanist nuns such as Tarabotti, “did not prompt the reconsideration of gender categories ... because nuns lived outside the reproductive economy," 148 I argue that the lives and

\footnotetext{
${ }^{147}$ Hurlburt, “A Renaissance for Renaissance Women?” 195.
}

148 Ross, The Birth of Feminism, 2. 
humanist endeavors of learned holy women were still largely determined by men. Past historiography has praised humanist nuns for trading a cloistered life for academic independence, but speaking of nuns as a monolithic group of women living outside the patriarchal system ignores the reality that a large percentage of women were cloistered by force and that their lives within convents continued to be, to a large extent, managed by the male-dominated social and ecclesiastical systems. For many cloistered women, humanism was the product of their forced monachization and not the impetus for their retreat from society. For these imprisoned women, the freedom to pursue a life of humanist scholarship came at a high price.

The patrimonial and patrilineal system of Renaissance Italy relied on intricate economic and social networks of familial allegiances to survive. The large urban centers of Northern Italy - namely Florence and Venice - filled convents with women from noble and merchant classes whose fathers could not provide a proper dowry or maintain their patrimony. ${ }^{149}$ The dowry and inheritance system, and the men who supported it, were the primary motives for funneling daughters into convents for economic gain and, in many instances, financial survival. The forced cloistering of young women, therefore, lied at the core of the social, political, and economic system of Northern Renaissance Italy. ${ }^{150}$ The transactions that occurred between women's fathers and either the fathers of their prospective mates or convents not only helped to sustain the patrimonial system, but also kept inflation down and the social hierarchy, which favored the wealthy elite, firmly

\footnotetext{
${ }^{149}$ Diana Maury Robin, Anne R. Larsen, and Carole Levine, Encyclopedia of Women in Renaissance: Italy, France, and England (Santa Barbara: ABC-CLIO. Inc., 2007), 92.

${ }_{150}$ Jutta Gisela Sperling, Convents and the Body Politic in Late Renaissance Venice (Chicago: University of Chicago Press, 1999), 32.
} 
intact. Simply put, patriarchal ideology supported the dowry system, and the dowry system supported convents.

Additionally, Catholic reform movements and the rise of Protestantism in Renaissance Italy during the fifteenth and sixteenth centuries increased patriarchal control of convents. Religious conflict, civic unrest, and instability in the patriarchal order were the impetuses for the enclosure movement, which was reestablished after the Council of Trent. ${ }^{151}$ Female convents were, in theory, physically and spiritually divorced from the outside world according to ecclesiastic tenants of enclosure: walls were built to enforce cloistering, nuns were not permitted any contact with family, and Communion was often mediated by male priests through small windows. ${ }^{152}$ While women often ran convents, they answered to men, and the patriarchal structure of the Catholic Church was firmly enforced by men. Priests, bishops, and ecclesiastic courts oversaw all convent activity, so although nuns did have greater freedom to engage in study, they were still subject to patriarchal control. In addition to reporting to the Church, "beginning in the fifteenth century, local civic authorities asserted the right to oversight of the convents in their jurisdiction." ${ }^{153}$ Civic leaders wanted to manage the activities of the convents, as well as their finances, to minimize opportunities for illicit relationships and influence from surrounding towns. As historian Jutta Gisela Sperling asserts, "Ecclesiastical and secular authorities charged with supervising convent discipline knew that involuntary monachizations were a constant source of disorder and scandal." ${ }^{\prime 54}$ The management of

\footnotetext{
${ }^{151}$ Robin, Larsen, and Levine, Encyclopedia of Women in Renaissance, 92.

152 Marilyn Dunn, "Invisibilia per visibilia: Roman Nuns, Art Patronage, and the Construction of Identity," in Wives, Widows, Mistresses, and Nuns in Early Modern Italy: Making the Invisible Visible through Art and Patronage, ed. Katherine A. McIver (Surrey: Ashgate, 2012), 181-5.

${ }^{153}$ Robin, Larsen, and Levine, Encyclopedia of Women in Renaissance, 94.

${ }^{154}$ Sperling, Convents and the Body Politic, 36.
} 
cloistered women, many of whom did not have the calling or propensity to enter into religious life, became a matter for both Church and civic officials, all of whom were men. Restrictions on the institutional life of nuns were enacted during the Renaissance, resulting in increased male supervision. ${ }^{155}$

Whether they became nuns by choice or by paternal design, it is clear that holy women still in some regard operated within the patriarchal system. Their vows and cloistered physical location did, however, remove them in some degree from society and provided them the opportunity to freely indulge in their studies and correspond with male scholars without reproach. As women situated in "the unworldly scholarly seclusion that male humanists 'officially' recommended as the ideal state for contemplative activity," 156 nuns were both chaste and overtly religious, and as such, also had more latitude in the content of their discourses. With their chastity preserved and their contact with society limited, nuns held a unique position in the humanist movement in Italy: unlike unmarried female humanists such as Isotta Nogarola, their vows protected them from the judgment of secular society, and unlike married scholars such as Moderata Fonte, their isolation allowed ample time for contemplation and writing. While this system was in many ways as socially oppressive as forced seclusion or marriage, cloistered humanist women like Arcangela Tarabotti often had the most prolific and esteemed scholarly careers.

Arcangela Tarabotti (1604-1652) was born into a large Venetian middle-class family as one of eleven children and the eldest of six daughters. Although little is known about her parents' social circumstances, Tarabotti's relationship with her family is well

\footnotetext{
${ }^{155}$ Margaret L. King and Albert Rabil, Jr., "Series Editor's Introduction” in Paternal Tyranny by Arcangela Tarabotti (Chicago: University of Chicago Press, 2004), xvii.

${ }^{156}$ Cox, "Women's Writings," 31.
} 
documented in her book Paternal Tyranny, which in addition to being an indictment of the Venetian patriarchal, patrimonial system is also a psychological autobiography on the cruelty of her childhood. ${ }^{157}$ Claiming that she was blackmailed by her brother with the argument that, "it is much better for one woman to be encloistered to serve God than for a whole family to go to rack and ruin," Tarabotti accused her family of being inhumane and violent after being sent to a Benedictine convent at eleven. ${ }^{158}$ Her indignation was based upon the social construction which concentrated familial wealth upon male children and bound daughters to convents for life against their will ${ }^{159}$ Tarabotti's destiny was determined by her family's economic circumstances.

\section{Life in a Cloistered Tomb}

Although she was forced to take religious orders at sixteen, Tarabotti initially refused to wear the religious habit or cut her hair, blaming both her parents and the convent for imprisoning her against her will and trying to strip her of virtue and identity. As a Benedictine, Tarabotti knew that she was bound to the same convent for life, which is why she referred to her new home as a tomb against which she rebelled. ${ }^{160}$ Her father, she claimed, followed the "diabolical suggestions about ridding [himself] of the line of inheritance" because she was physically disabled; like other fathers of the time, he did "not offer as brides of Jesus [his] most beautiful and virtuous daughters, but the most repulsive and deformed: lame, hunchbacked, crippled, or simple-minded ... condemned to lifelong prison." ${ }^{" 161}$ Extremely self-conscious about her abnormal appearance, Tarabotti

\footnotetext{
${ }^{157}$ Letizia Panizza, "Volume Editor's Introduction" in Paternal Tyranny by Arcangela Tarabotti (Chicago: University of Chicago Press, 2004), 1.

${ }^{158}$ Arcangela Tarabotti, Paternal Tyranny, 246, cited in Letizia Panizza and Sharon Wood, History of Women's Writings in Italy (Cambridge: Cambridge University Press, 2000), 76.

${ }^{159}$ Ibid., 74.

160 Panizza, "Volume Editor's Introduction," 4.

${ }^{161}$ Tarabotti, Paternal Tyranny (Chicago: University of Chicago Press, 2004), 66, 90.
} 
confessed: "I have always had this maxim engraved in my memory: that without chastity no woman is beautiful ... recognizing that I am ugly and maimed in body, I have devoted myself to cultivating beauty of soul as the only kind that deserves to be desired and admired." 162 It was through the cultivation of her mind that Tarabotti compensated for what she perceived of as abhorrent physical impairments. Her work reflected the pain and indignation she felt at being rejected both by her family and society. As Tarabotti biographer Letizia Panizza argues, "Tarabotti did not refer to herself as a nun, but as a laywoman unjustly sentenced to life-imprisonment in a monastery, whose mission it is to reveal to the world the duplicity and injustice of the patriarchs - fathers, and civil and religious authorities." ${ }^{163}$ Although socially relegated to a life of monastic imprisonment, Tarabotti's work showed no resignation of spirit.

As a whole, Tarabotti's discourses are a dialectical opposition to the patrilineal system and an indictment of the misogynistic practice of selling daughters into marriage or confining them to a convent to empower men and systematically imprison women. In the opening of her most famous work, Paternal Tyranny, Tarabotti writes a dedication to the Venetian Republic which states:

From the first foundations of your city on these lagoons, Fame penetrated its depths and drew forth Paternal Tyranny ... this [book] is a gift that well suits a Republic that practices the abuse of forcing more young girls to take the veil than anywhere else in the world ... I declare explicitly that there is no intention in my writings to criticize religion itself or to enter into debates - except against those fathers and relatives who act violently in making their daughters don the religious habit. ${ }^{164}$

\footnotetext{
${ }^{162}$ Ibid., 155.

${ }^{163}$ Leticia Panizza and Sharon Wood, A History of Women's Writing in Italy (Cambridge; Cambridge University Press, 2000), 74.

${ }^{164}$ Tarabotti, Paternal Tyranny, 37-8.
} 
After addressing both God and her reader about the honorable, yet humble, intentions of her work, Tarabotti begins the first book of her discourse by again lambasting the patriarchal Venetian system and "The Crime of Enforced Enclosure":

Men's depravity could not have devised a more heinous crime than the wanton defiance of God's inviolable decrees. Yet day in and day out, men never cease defying them by deeds dictated by self-interest.

Among their blameworthy excesses, pride of place must go to enclosing innocent women within convent walls under apparently hold (but really wicked) pretexts ... They come into the world tainted by sinful dispositions. What a gross abuse, what an unforgivable error, what a wicked decision, and what sheer audacity is this deed. ${ }^{165}$

The vehemence against both family and state is clear; her indictment of both religious personages and civil institutions direct. ${ }^{166}$ Men of the cloth, the state, and her family have conspired to systematically disempower and imprison women for their own material and social benefit.

Although classically educated and well-versed in the academic discourses of her time, Tarabotti clearly attacked the patriarchal system which denied many women outside of convents a sufficient education. Humanist education was seen, at least theoretically, as cultivating a virtuous spirit, but for cloistered women like Tarabotti, this ideal must have seemed a painful contradiction. In her assessment, men deprived women of education, and thus freedom, in one of two ways: learned women were often socially powerless because they were entombed in convents and non-cloistered women were denied learning to keep them ignorant and easy to oppress. Tarabotti's denunciation of this practice reads:

Do not scorn the quality of women's intelligence, you malignant and evil-tongued men! Shut up in their rooms, denied access to books and teachers of any learning

\footnotetext{
${ }^{165}$ Ibid.

${ }^{166}$ Daniela De Bellis, "Attacking Sumptuary Laws in Seicento Venice: Arcangela Tarabotti," in Women in Italian Renaissance Culture and Society, ed. by Letizia Panizza (London: Modern Humanities Research Association and Maney Printing, 2000), 227.
} 
whatsoever, or any other grounding in letters, they cannot help being inept in making speeches and foolish in giving advice. Yours is the blame, for in your envy you deprive them of the means to acquire knowledge. ${ }^{167}$

Her work, Antisatira, similarly argues than women should be liberated from the chains of ignorance and fight against the masculine oppression which invalidates their intellectual dignity and relegates them to the home or convent. ${ }^{168}$ By denying women an education or forcing them into monastic seclusion, men are, in Tarabotti's estimation, depriving women of the necessary skills and weapons to adequately protest their own subordination. Education, a privilege of male tyranny, is the primary tool of patriarchal oppression.

\section{Influence Outside the Covent Walls}

In spite of Tarabotti's controversial and bold condemnation of the Venetian Republic, patrilineal practices, and ecclesiastic life, her work was well-received in prominent intellectual circles. While church officials in the Holy Office and Venetian patricians were extremely critical of her work on the grounds that it was socially and religiously subversive, she was highly praised by wealthy Venetian secular humanists, who both published and distributed her works in their circles. ${ }^{169}$ "To some extent, Tarabotti's persona of the unlettered nun cut off from the world of learning is a ruse serving to deflect criticism but also to draw approval for what she has accomplished under such adverse circumstances." ${ }^{" 170}$ As a female intellectual living an asexual existence, not unlike Isotta Nogarola in her later life, Tarabotti's engagement with male scholars was also viewed as socially acceptable rather than indecent; she was valued for

\footnotetext{
167 Tarabotti, Paternal Tyranny, 99.

${ }^{168}$ De Bellis, "Attacking Sumptuary Laws," 227-8.

169 Panizza, "Volume Editor's Introduction," 7.

${ }^{170}$ Ibid.
} 
her contemplative counsel. ${ }^{171}$ As Boccaccio pointed out centuries earlier, powerful women could be honorable if their chastity was protected because their claritas, or virtue, preserved the honor of both their family and state. ${ }^{172}$ As such a protected figure, Tarabotti used her chastity - albeit forced - to her advantage, and was given greater intellectual and social latitude because of her circumstance.

Some men, many of whom had sisters locked away in convents, were sympathetic to Tarabotti's plight. Scholars in the prestigious Venetian literary academy, the Incogniti, also saw Tarabotti as a female ally in their assault on the Catholic Church. Giovanni Francesco Loredan, founder of the Incogniti, is thought to have been introduced to Tarabotti through her brother-in-law and acted as a champion patron for her works. ${ }^{173}$ Tarabotti constructed her humanist identity based on her association with powerful Incogniti members, and published dedications to her male patrons to further legitimize her place as a prominent intellectual. ${ }^{174}$ Like Moderata Fonte, Tarabotti aligned herself with patriarchal figures who could financially and socially support her ambition, and these associations were a large factor in her success. In her biography of Tarabotti, whom she argues had the unique position of being the only woman in Venice to enjoy the patronage of distinguished male aristocrats, historian Letizia Panizza argues:

She had achieved her goal as a literary figure who corresponded as a social and intellectual equal with members of the Venetian elite: aristocracy, clergy, and the top men of letters of her age ... [her] letters testify to a cultural exchange between peers: Tarabotti sends out her own works and asks for advice and comments, but she also receives works of other writers and is sometimes asked for advice. ${ }^{175}$

\footnotetext{
${ }^{171}$ Hurlburt, “A Renaissance for Renaissance Women?” 195.

172 Contrada, "The Civic Virtue," 175.

173 Panizza, "Volume Editor's Introduction," 7.

${ }^{174}$ Saundra Weedle, "Letters Familiar and Formal by Arcangela Tarabotti." Review of Arcangela Tarabotti. Letters Familiar and Formal, ed. Meredith K. Ray and Lynn Laura Westwater in Renaissance Quarterly 66, no. 4 (Winter 2013): 1489.

175 Ibid., 12.
} 
Clearly respected for both her intellect and writing ability, Tarabotti successfully expanded her circle of influence outside of the convent walls. She corresponded with intellectuals to garner support for her work and her protest against the forced monachization of young girls. Praised by other humanist authors for her "keenness" and a "glory to her sex"176 in their literary dedications to Tarabotti, she became a symbol not only of female humanism, but of the "anti-Catholic sentiments" that were being spread by many of the Incogniti's members. ${ }^{177}$ It is important to note as well that some of her works were published anonymously, which further sheltered her from ecclesiastic retribution. Before her death at the age of forty-eight, the self-described "ignorant woman" ${ }^{178}$ had tremendous influence within the impressive intellectual community of her city.

Although famous for her criticism of the misogynistic and oppressive patriarchal system of Venice, Tarabotti did navigate her academic career from within its borders. Her attacks on the patrilineal system and the cloistering of young girls against their will were aggressive, but they were actually consistent with the official proclamation of Giovanni Tiepolo, patriarch of Venice from 1619-1631, which stated that nuns were in convents, "not because of religious motivation, but pushed by their own family." ${ }^{179}$ Similarly, although her condemnation of paternal tyranny - specifically the practice of denying girls an education - was viewed by some as subversive, it was lobbied from within the confines of a convent managed by the male-run Catholic Church. As Tarabotti herself made clear in both her works Convent Life as Inferno and Paternal Tyranny, nuns are, "entangled in a net from which they cannot extricate themselves, a net woven by human

\footnotetext{
${ }^{176}$ Ibid., 8.

${ }^{177}$ Ibid.

178 Tarabotti, Paternal Tyranny, 156.

${ }^{179}$ Ibid., 4.
} 
malice, stronger and more difficult to loosen than the god Vulcan's. They despair of finding an escape and live dying, if they live at all, tormented by a thousand rages and anxieties - their bodies bound up in religious habits and their souls ready to fall into Hell's abyss." ${ }^{180}$ Tarabotti had a strong, influential voice within humanist circles, but little actual power.

Arcangela Tarabotti was, in many ways, a product of seventeenth-century humanism: she participated in a firmly-established tradition of providing a classical education to select upper-class women and nuns, she engaged in intellectual discourses with other learned figures, and she challenged oppressive Catholic ideology. While she academically benefitted from her position as a religious woman, her life, destiny, and the publication and circulation of her works were still controlled by men. Unlike Isotta Nogarola, whose choice to remain unmarried threatened her chastity, Laura Cereta, whose attacks on patriarchy were viewed as indecorous and subversive, and Moderata Fonte, whose engagement in humanism was limited by marriage and children, nun Arcangela Tarabotti's traditional place in the patriarchal order allowed her both the time and social protection to fully indulge her academic pursuits. Without the support of patriarchal figures outside of the convent, however, Tarabotti's contribution to the humanist movement might have remained unappreciated, for the men who sponsored and legitimized her work ultimately ensured her legacy. She could be praised for her writings by fellow humanists and tolerated by ecclesiastic officials because, in reality, a cloistered woman was of little danger to the stability of the Republic or the Church. Neither her

${ }^{180}$ Tarabotti, Paternal Tyranny, 71. 
scholastic pursuits nor her condemnation truly threatened the patriarchal system in which she only peripherally operated. 


\section{THE LEGACY OF RENAISSANCE PROTOFEMINISTS}

Of women's participation in the Renaissance, Joan Kelly-Gadol writes that, "Development reorganized Italian society along modern lines and opened the possibilities for the social and cultural expression for which the age is known. Yet precisely these developments affected women adversely, so much so that there was no renaissance for women - at least, not during the Renaissance." 181 While I agree that women were certainly not liberated by the social, economic, and political changes that occurred in the transitory time between the Middle Ages and the early modern period, Kelly-Gadol's assessment that women did not experience any type of renaissance is a sweeping generalization. As is made evident in this investigation, the scholastic lives of notable Italian female humanists, in particular Isotta Nogarola, Laura Cereta, Moderata Fonte, and Arcangela Tarabotti, pose a challenge to the claim that women were systematically excluded from the social and cultural expressions of the Renaissance period.

The intellectual lives and published works of notable Italian female humanists all in some manner challenged Renaissance patriarchy and the disenfranchisement of women. As Sarah Ross adeptly argues, “[women] emboldened by an awareness that they participated in an unbroken succession of learned women from antiquity to their own times, brought a new level of intensity to the [equality] debate." 182 Humanist women,

\footnotetext{
${ }^{181}$ Bridenthal and Koonz, Becoming Visible, 175.

182 Ross, The Birth of Feminism, 276.
} 
namely those who were raised within intellectual families, were granted educational opportunities not before afforded to members of their sex and employed this knowledge to the service of their individual societies. As humanism became more deeply embedded in Renaissance culture, and as women gained more authority in the movement, a greater precedence was set for female education. Italian female humanists of the late Renaissance period, most notably Arcangela Tarabotti, made significant contributions to the protofeminist movement by demanding radical changes be made to the patriarchal system. ${ }^{183}$ Although these changes were not immediately evident, learned women were active participants in the humanist and civic dialogues of their time, and their works became valuable additions to the protofeminist literary canon. While the renaissance they experienced did not dramatically alter their immediate sociopolitical experience, as Margaret King reminds historians, "Something changed during the Renaissance in women's sense of themselves ... [which] culminates in the consciousness put into words by the first feminists of the Renaissance. Not monsters, not defects in nature, but the intelligent seekers of a new way, these women wielded the picks of their understanding to build a better city for ladies." 184 The works discussed here are just a small sampling of those written by Italian female humanists that reflected that evolution of thought and spirit.

This thesis offers a framework for analyzing and appreciating the ways in which learned women participated in the humanist dialogue of their time once past the age of sexual maturity. Clearly, the patriarchal construction of Renaissance society did, to a large extent, determine the course of a female humanist's career and her public reception.

\footnotetext{
${ }^{183}$ Contrada, "The Civic Virtue," 166.

${ }^{184}$ King, Women of the Renaissance, 238-9.
} 
The social value of chastity, concepts of Christian virtue, and the well-entrenched patrilineal system influenced the opportunities afforded to and the limitations imposed upon learned women once they reached the age of adulthood or began to operate outside of a paternal figure's supervision. Women who assumed an acceptable sociallyconstructed role within the patriarchal order generally had a positive social and academic reception to their work; women who resisted traditional prescriptions of femininity were often ostracized or forced by social conventions to discontinue their studies. To fully analyze the myriad of ways in which learned adult women participated in humanism more narrowly, and in the Renaissance more broadly, however, their engagement with paternal figures, patrons, and patriarchal institutions must be appreciated on an individual basis.

In The Birth of Feminism, Sarah Ross has provided historians with an invaluable model for understanding "the intellectual family" and how the early paternal academic training of many young female humanists can be conceptualized. By extending, and in some places challenging, Ross's argument as it applies to women outside of adolescence, I have endeavored to push historians to examine childhood training and adult vocation separately. Thus, this thesis, in part, challenges the notion that "exceptionality" either ended with childhood or became equated with social marginality. Additionally, viewing adult female humanists in the "role of mascots [rather] than fully integrated members of the professional humanistic community," ${ }^{185}$ as Virginia Cox suggests, further obscures their individual social and academic experiences, career longevity, and public reception; it is faulty to believe that, "there was no room in [Renaissance] society for adult female

\footnotetext{
${ }^{185}$ Cox, Women's Writings in Italy, 8.
} 
humanists once they were no longer amusing child prodigies." ${ }^{186}$ I have presented the case studies of Isotta Nogarola, Laura Cereta, Moderata Fonte, and Arcangela Tarabotti not to argue that these women were anomalies for extending their scholastic pursuits into adulthood, but to illustrate that they were not. Women such as Cassandra Fedele, Veronica Franco, Lucrezia Marinella, and Ippolita Maria Sforza also published impressive works which attest to the large community of learned women who participated in the academic dialogues of their time. Many of these authors saw themselves not as "other," but as an extension of a long line of illustrious, accomplished women. They were not oddities, but legacies.

Furthermore, this thesis makes the larger argument that an adult humanist woman's public reception and career longevity were dependent upon her willingness to adhere to patriarchal ideology and conform to traditional prescriptions of femininity, and were not simply a result of her age or marital status. While previous scholarship has rightfully challenged the notion that educated females were anomalies, it has still largely embraced the idea that women simply abandoned academics in favor of marriage without analyzing the circumstances which led women to cease publishing. Drawing this hard line between childhood education and marriage underappreciates the complex relationships adult female humanists forged with their male supporters and the ways in which women strategically balanced social expectations with academic ambition. I argue, with my case studies as evidence, that relying solely on the father-daughter paradigm of tutelage and patronage to understand the totality of women's experience with humanism is limited. Scholars must examine individual women's experiences, and why those who

\footnotetext{
${ }^{186}$ Contrada, "The Civic Virtue," 187.
} 
abandoned their studies chose or were forced to do so, and how those who successfully continued to engage with humanism secured social and academic support for their endeavor.

Isotta Nogarola's experience demonstrates that early female humanists in quattrocento Italy were expected to abandon their studies for either marriage or religious life after reaching an age of sexual maturity. As a young protégé of Veronese society, Nogarola was praised for her erudition; what is important to note, however, is that much of the praise she was given as a young scholar was tied to her city, her male relatives, and her connection with male humanists. She was widely praised when she was a reflection of an individual man or patriarchal institution. Nogarola's only personal virtue truly lauded in her contemporaries' letters was her virginity, so when she professed as an adult woman that she desired to remain an unmarried scholar, the patriarchal order attacked. When she later attempted to position herself outside of Veronese society, she no longer had either the social connections or her virtuosity to rely on and was socially ostracized. Her desire for autonomy was equated with immorality, and both her academic and personal reputation were tarnished as a result. It was not until she removed herself from society that she found social and academic acceptance when her chastity was again secured. Isotta Nogarola's academic and social reception were directly tied to her willingness to adhere to proper prescriptions of femininity.

Similarly, an analysis of Laura Cereta's life and works makes evident the connection between a learned woman's social acceptance and the patriarchal order. Although she was always an outspoken critic of both men and women alike, Cereta was allowed to participate in the humanist community in a meaningful way because of the 
social and financial support of her influential father. Her arrogance and excessive social visibility, however, were deterrents to other prominent male patrons, so when Cereta's father died, she was left without an ally. She refused to comply with the patriarchal order and gender norms, and the genre of her writing was not deemed appropriately feminine. Without a legitimate patron or patriarchal institution to support her endeavors, Cereta lacked the social and economic capital to continue her studies.

Moderata Fonte, on the other hand, found acceptance and support in the humanist community because she complied with patriarchal gender ideology. Although married and the mother of four children, Fonte continued her academic training and published well-respected dialogues, effectively refuting Margaret King's assertion that marriage, "inhibited the learned woman from pursuing studious interests, and certainly prevented her from ambitions she might have cherished for greatness" or that "at the very moment that they praised learned women, learned men undermined them." ${ }^{187}$ While it is certainly true that marriage complicated Fonte's studies and that some learned men saw accomplished women as a threat, Fonte successfully balanced her academic and social life. By writing in a rhetorically-appropriate genre for a woman, structuring her works in the hypothetical, publishing under a nom de plume, and maintaining low social visibility, Fonte strategically walked the line between challenging and complying with the social order. More importantly, she secured the support of a powerful male patron who both promoted and legitimized her work. The success and longevity of Moderata Fonte's career were a direct product of her adherence to traditional social and gender ideology.

\footnotetext{
${ }^{187}$ King, "Book-Lined Cells," 69.
} 
Arcangela Tarabotti's life and work stand as a direct challenge to historians' discussion of nuns as completely standing outside of the patriarchal system. Sold to a convent as a young girl, Tarabotti did exist outside of the reproductive economy once she was cloistered. The socioeconomic system which led to her cloistered existence, however, was intrinsically bound to the patrilineal, patrimonial system of Renaissance Italy. Furthermore, although she took religious orders, Tarabotti's life and academic work were still constantly subject to male oversight: ecclesiastic leaders censured her writings, prominent humanist patrons published and circulated her books, and civic leaders maintained jurisdiction over convent life. Tarabotti, like Moderata Fonte, chose to strategically align herself with patriarchal figures to increase her academic visibility. As a nun, she assumed a socially acceptable role in Renaissance society, and it was her connection with the Church and male patrons which allowed her to indulge in her academic pursuits without being perceived as transgressing social gender conventions. As a nun, she lived a cloistered existence, and as a female humanist, she was dependent on patriarchal society to legitimately continue publishing her works.

Although earlier I advocated that women not be reduced to a monolithic group or collective Renaissance experience, it is valuable at this point to transition back from the micro to the macro. Italian female humanists did in many ways have a shared experience of lobbying for and representing the "learned woman" in Renaissance society. Their social and academic opportunities were limited by their gender, and yet, they all managed to participate in the humanist milieu of Renaissance Italy in a meaningful way at some point in their adult lives. It is appropriate that historians seek to understand this collective of learned Renaissance women to better understand the progression of social ideology, 
female education, and feminist thought. That said, the questions that historians ask and the answers they propose cannot be based on generalizations and homogeneous notions of shared experiences so much so that individuals' lives are obscured. This thesis, therefore, suggests that historians continue to ask how adult women's experiences were determined by their sexual maturity, marital choices, and relationship with paternal figures, and even more importantly, how adult women continued to meaningfully participate in society in spite of socially mandated limitations on their gender. The experiences of Renaissance women who were both willing and unwilling to comply with patriarchal ideology and prescriptions of femininity all in some way reflect the psychosocial changes that Margaret King spoke of. The bias of the historical record must also continue to be challenged, namely the misogynistic terms that have been used to describe learned women as social oddities. I am grateful to Margaret King and Albert Rabil, Jr. for editing The Other Voices in Early Modern Europe series, for the primary sources the series have published have given so many learned women from history a voice in today's world; women must be allowed to speak for themselves when they can do so, even from the past. By continuing to translate and study women's own works, the degree to which women experienced the Renaissance will undoubtedly be further illuminated and appreciated.

To be termed a "protofeminist" by historians, a woman should not have had to completely renounce every patriarchal institution or prescription of femininity. Feminists have often challenged sexual inequality and patriarchy by strategically working from within the system. Such is the case with the Renaissance protofeminists discussed here. They did not advocate for women's intellectual and social inequality by completely 
divorcing themselves from their sex or "becoming men," even when encouraged to do so. They found ways to share their female voice, and did so most successfully when they utilized patriarchal figures and structures to their advantage. Their advocacy for gender equality and commitment to learning was directly tied to the humanist movement and the educational opportunities it afforded women; they were certainly granted opportunities not fathomable to most of their medieval predecessors. Protofeminists Isotta Nogarola, Laura Cereta, Moderata Fonte, and Arcangela Tarabotti are evidence that some women experienced a renaissance and greatly contributed to the evolution of feminist thought and female education. As such, these Renaissance female humanists should certainly not be classified as "merely decorative." 188

${ }^{188}$ King and Rabil, Teaching Other Voices, 194. 


\section{REFERENCES}

Abel, E. Isotae Nogarolae Veronesis opera quae supersunt omnia. Budapest, 1886.

Betussi, Giuseppe. Libra di M. Gio. Boccaccio delle donne illustri, tradotto per Giuseppe Betussi. Venice: Pietro de Nicolini de Sabbio, 1547.

Black, Robert. "Italian Renaissance Education: Changing Perspectives and Continuing Controversies." Journal of the History of Ideas 52, no.2 (1991): 315-34.

Blade, Melinda K. Education of Italian Renaissance Women. Mesquite: Ide House, 1983.

Boršić, Luka, and Ivana Skuhala Karasman. "Isotta Nogarola - the Beginning of Gender Equality in Europe." Monist 98, no. 1 (2015): 43-52.

Bridenthal, Renate, and Claudia Koonz. Becoming Visible: Women in European History. Boston: Houghton Mifflin, 1977.

Cereta, Laura. Laura Cereta Brixiensis Feminae Clarissimae Epistolae iam primum e MS in lucem productae. Edited by Jacopo Filippo Tomasini. Padua: Sebastiano Sardi, 1640.

- Collected Letters of a Renaissance Feminist. Edited and translated by Diana Robin. Chicago: University of Chicago Press, 1997.

Contrada, Christine. "The Civic Virtue of Women in Quattrocento Florence.” PhD diss., State University of New York at Stony Brook, 2010.

Cox, Virginia. Introduction to The Worth of Women by Moderata Fonte. Chicago: University of Chicago Press, 1997.

- Women's Writing in Italy, 1400-1650. Baltimore: Johns Hopkins University Press, 2008.

De Bellis, Daniela. "Attacking Sumptuary Laws in Seicento Venice: Arcangela Tarabotti." In Women in Italian Renaissance Culture and Society edited by Letizia Panizza, 227-242. London: Modern Humanities Research Association and Maney Printing, 2000.

Dunn, Marilyn. "Invisibilia per visibilia: Roman Nuns, Art Patronage, and the Construction of Identity." In Wives, Widows, Mistresses, and Nuns in Early 
Modern Italy: Making the Invisible Visible through Art and Patronage. Edited by Katherine A. McIver. Surrey: Ashgate, 2012.

Durant, Will. The Renaissance: A History of Civilization in Italy from 1304-1576. New York: Simon and Schuster, 1953.

Edwards, J. Stephan. "A Woman is Wise: The Influence of Civic and Christian Humanism on the Education of Women in Northern Italy and England During the Renaissance." PhD diss., 2002.

Evangelisti, Silvia. "Learning from Home: Discourses on Education and Domestic Visual Culture in Early Modern Italy." History 98, no. 333 (2013): 663-79.

Findlen, Paula. The Italian Renaissance: The Essential Readings. Malden: Blackwell Publishing, 2002.

Fonte, Moderata. The Worth of Women. Edited and translated by Virginia Cox. Chicago: University of Chicago Press, 1997.

Gibson, Joan. "Educating for Silence: Renaissance Women and the Language Arts." Hypatia 4, no. 1 (1989): 9-27.

Gill, Amyrose McCue. "Fraught Relations in the Letters of Laura Cereta: Marriage, Friendship, and Humanist Epistolarity." Renaissance Quarterly 62, no. 4 (Winter 2009): 1098-129.

Hurlburt, Holly S. “A Renaissance for Renaissance Women?” Journal of Women's History 19, no. 2 (2007): 193-201.

Jardine, Lisa. "Isotta Nogarola: Women Humanists - Education for What?" In The Italian Renaissance, edited by Paula Findlen, 273-91. Malden: Blackwell Publishing, 2002.

_ " "O Decus Italiae Virgo', or the Myth of the Learned Lady in the Renaissance." The Historical Journal 28, no. 4 (1985): 799-819.

Jordan, Constance. Renaissance Feminism: Literary Texts and Political Models. Ithaca: Cornell University Press, 1991.

King, Margaret L. "Book-Lined Cells: Women and Humanism In The Early Italian Renaissance." In Beyond Their Sex: Learned Women of the European Past. Edited by Patricia Labalme, 66-90. New York: New York University Press, 1980.

_. "Petrarch, Self-Conscious Self, and the First Women Humanists." Journal of Medieval and Early Modern Studies 35, no. 3 (Fall 2005): 537-58. 
—. "The Religious Retreat of Isotta Nogarola (1418-1466): Sexism and Its

Consequences in the Fifteenth Century." Signs 3, no. 4 (1978): 807-22.

- Renaissance Humanism: An Anthology of Sources. Indianapolis: Hackett Publishing Company, 2014.

—. "Thwarted Ambitions: Six Learned Women of the Italian Renaissance." Soundings: An Interdisciplinary Journal 59, no. 3 (Fall 1976): 280-304.

- Women of the Renaissance. Chicago: University of Chicago Press, 1991.

King, Margaret L., and Albert Rabil, Jr. Her Immaculate Hand: Selected Works by and About the Women Humanists of Quattrocento Italy. Binghamton: Medieval and Renaissance Texts and Studies, 1992.

_. "Series Editor's Introduction." In Paternal Tyrrany by Arcangela Tarabotti. Chicago: University of Chicago Press, 2007.

- Teaching Other Voices: Women and Religion in Early Modern Europe. Chicago: University of Chicago Press, 2007.

King, Margaret L., and Diana Maury Robin. Introduction to Complete Writings:

Letterbook, Dialogue on Adam and Eve, Orations by Isotta Nogarola. Chicago: University of Chicago Press, 2004.

Labalme, Patricia H. Beyond Their Sex: Learned Women of the European Past. New York: New York University Press, 1980.

- "Venetian Women on Women: Three Early Modern Feminists." Archivo Veneto, 117 (1981): 81-109.

Mitchell, Joseph R., and Helen Buss Mitchell. Taking Sides: Clashing Views on Controversial Issues in Western Civilization, $1^{\text {st }}$ edition. Guildford: Dushkin/McGraw-Hill, 2000.

Nogarola, Isotta. Complete Writings: Letterbook, Dialogue on Adam and Eve, Orations. Edited and translated by Margaret King and Diana Maury Robin. Chicago: University of Chicago Press, 2004.

Panizza, Letizia. Introduction to Paternal Tyranny by Arcangela Tarabotti. Edited and translated by Letizia Panizza. Chicago: University of Chicago Press, 2004.

— .The Fifteenth Century: Humanism." In A History of Women's Writing in Italy. Edited by Letizia Panizza and Sharon Wood, 25-30. Cambridge: Cambridge University Press, 2000. 
Panizza, Letizia, and Sharon Wood. A History of Women's Writing in Italy. Cambridge: Cambridge University Press, 2000.

Price, Malpezzi. Moderata Fonte. Danvers: Rosemont Publishing and Printing Corporation, 2003.

_- "Venetia Figurata and Women in Sixteenth-Century Venice." In Italian Woman and the City: Essays, edited by Janet Smarr and Daria Valentini, 18-33. Madison: Fairleigh Dickinson University Press, 2003.

Robin, Diana Maury, Anne R. Larsen, and Carole Levine. Encyclopedia of Women in Renaissance: Italy, France, and England. Santa Barbara: ABC-CLIO. Inc., 2007.

Ross, Sarah Gwyneth. The Birth of Feminism: Women as Intellect in Renaissance Italy and England. Cambridge: Harvard University Press, 2009.

Rossi, Daniella, and Nadia Cannata Salamone. "Italian Studies: Humanism and Renaissance.” The Year's Work in Modern Language Studies 71 (2011): 442-59.

Ruggiero, Guido. The Renaissance in Italy: a Social and Cultural History of the Rinascimento. Cambridge: Cambridge University Press, 2014.

Schibanoff, Susan. "Botticelli's Madonna Del Magnificat: Constructing the Woman Writer in Early Humanist Italy." PMLA 109, no. 2 (1994): 190-206.

Smarr, Janet. Joining the Conversation: Dialogues by Renaissance Women. Ann Arbor: University of Michigan Press, 2005.

_. "The Uses of Conversation: Moderata Fonte and Edmund Tilney." Comparative Literature 32, no. 1 (1995): 1-25.

Smarr, Janet, and Daria Valentini. Italian Women and the City: Essays. Madison: Fairleigh Dickinson University Press, 2003.

Sperling, Jutta Gisela. Convents and the Body Politic in Late Renaissance Venice. Chicago: University of Chicago Press, 1999.

Tarabotti, Arcangela. Paternal Tyranny. Edited and translated by Letizia Panizza. Chicago: University of Chicago Press, 2004.

Weedle, Saundra. "Letters Familiar and Formal by Arcangela Tarabotti." Review of Arcangela Tarabotti. Letters Familiar and Formal. Edited by Meredith K. Ray and Lynn Laura Westwater. Renaissance Quarterly 66, no. 4 (Winter 2013): 1488-90. 


\section{CURRICULUM VITA}

NAME:

ADDRESS:

DOB:

EDUCATION

\& TRAINING:
Julie Elizabeth Myers-Mushkin

9201 Ash Land Ct.

Pewee Valley, KY 40056

Salinas, California - March 10, 1976

University of Louisville

Masters Candidate in Women's and Gender Studies, 2015-present Fields: Renaissance, Early Modern Europe, Women's History (Genevieve Carlton)

Thesis: 'The Quality of Women's Intelligence': Female Humanists in Renaissance Italy

University of Louisville

Candidate for the Graduate Certificate in Medieval and Renaissance Studies, 2015-present

Fields: Renaissance, Early Modern Europe, Women's History

(Genevieve Carlton)

Thesis: 'The Quality of Women's Intelligence': Female Humanists in Renaissance Italy

Simpson University

California Clear Multiple Subject Teaching Credential and Single Subject Teaching Credential (Social Studies), 2004-2005

University of California, Los Angeles

B.A., History cum laude

Fields: World religions and early Christian history (S.Scott

Bartchy)

1994-1998

University of California, Los Angeles

B.A., Study of Religion cum laude

Fields: World religions and early Christian history (S. Scott

Bartchy)

1994-1995 
TEACHING AND

RELEVANT

EXPERIENCE: $\quad$ Seventh Grade Language Arts and Social Studies Teacher, Present

St. Francis School, Goshen, KY

Scantron Corporation and Global Scholar, 2011-Present

Contracted subject matter expert in Social Studies and English

Language Arts

Social Studies Teacher, 2000-2001

Notre Dame High School, Salinas, CA

Third Grade Teacher, 1998-2000

Roosevelt Elementary School, Salinas, CA

English Teacher, 1998

North Salinas High School

CERTIFICATIONS: KEL: Kentucky Professional Certificate for Teaching in

Elementary School, Primary Through Grade 5

KG20: Kentucky Professional Certificate for Middle Grades Social Studies, Grades 5 Through 9

KSS: Kentucky Professional Certificate for Teaching Social Studies, Grades 8 Through 12

AWARDS: “Outstanding Young Educator," 1999

Salinas Jaycee's, Salinas, CA

"Outstanding Young Educator," 2000

Salinas Jaycee's, Salinas, CA
PROFESSIONAL SOCIETIES:
Golden Key National Service Honor Society, UCLA Chapter

Phi Alpha Theta National History Honor Society, UCLA Chapter 